\title{
Effect of Initial Wettability on Rock Mechanics and Oil Recovery: Comparative Study on Outcrop Chalks
}

\author{
Jaspreet S. Sachdeva ${ }^{1,2}$ (D) $\cdot$ Anders Nermoen ${ }^{1,3} \cdot$ Reidar I. Korsnes $^{1,2}$. \\ Merete V. Madland ${ }^{1,2}$
}

Received: 17 April 2019 / Accepted: 25 April 2020 / Published online: 6 May 2020

(c) The Author(s) 2020

\begin{abstract}
Brines containing surface-active divalent ions such as $\mathrm{Ca}^{2+}, \mathrm{Mg}^{2+}$ and $\mathrm{SO}_{4}{ }^{2-}$ impact the stiffness, strength and time-dependent deformation of water wet Mons outcrop chalk. This study documents how stiffness and strength of wettability-altered oil and water-saturated (mixed wet) Mons chalk compare to water-saturated and water wet samples during hydrostatic loading and creep. During hydrostatic creep, the strain rate response to magnesium chloride $\left(\mathrm{MgCl}_{2}\right)$ brine injection is compared for water wet and mixed wet samples. For the mixed wet samples, the oil production was estimated during compaction and non-equilibrium $\mathrm{MgCl}_{2}$ flow. The results presented here were then compared to a similar test series on Kansas outcrop chalk. The differences were interpreted in terms of difference in physical parameters such as porosity and pore size. Two Mons samples were wettability-altered and tested in parallel to two completely water wet samples from the same chalk block at hydrostatic conditions and $130{ }^{\circ} \mathrm{C}$. It was found that beyond the experimental uncertainty, the stiffness and yield strength measurements showed insignificant differences for water wet and mixed wet Mons samples. This is contrary to Kansas chalk where mixed wet samples were systematically stronger and stiffer than water wet samples. In the following creep phase, both water wet and wettability-altered Mons chalk samples gave trends comparable to each other during a stagnant phase and a following $\mathrm{MgCl}_{2}$ injection phase at varying flow rates. Similar observations were reported for water wet and wettability-altered Kansas chalks as well. Further, the same chemical reactions were observed for Kansas and Mons chalks and were found to be insensitive to the initial wettability and oil/water saturations. The oil production observations from Mons chalk showed that $43 \%$ of the total oil was recovered during early-stage compaction with no flow, whereas Kansas chalk did not produce any oil at no-flow conditions. After the oil recovery from the first $2-3$ pore volumes of brine flow, no further oil production was observed due to compaction or non-equilibrium brine flow in any of the two chalk types.
\end{abstract}

Keywords Improved oil recovery · Water flooding · Chalk compaction · Wettability · Geomechanics · Oil production measurements

Jaspreet S. Sachdeva

jaspreet.s.sachdeva@uis.no

Extended author information available on the last page of the article 


\section{Introduction}

The physico-chemical interactions between the resident fluids, the injected fluids and the reservoir rock impact the mechanical rock properties of chalk. Chalk is a highly porous and a low permeable rock. Due to the large surface area in chalk, surface processes (dissolution/ precipitation and adsorption/desorption) dominate the bulk mechanical behaviour. Studies have shown that seawater injection into reservoir chalks lead to enhanced compaction, hence driving pore fluids towards production facilities and thereby leading to improved oil recovery (Sulak and Danielsen 1989; Sulak 1991; Hermansen et al. 2000). The enhanced reservoir compaction also induced seafloor subsidence raising serious concerns related to the safety of personnel on the platforms, the equipment and wellbore stability (Sulak and Danielsen 1989; Maury et al. 1996; Nagel 1998; Sylte et al. 1999; Gauer et al. 2002). This compaction was found to be caused by both pore pressure depletion early in the field life and the water weakening induced by seawater injection during the later stages (Gauer et al. 2002).

Research on how chalk mechanics was affected by pore fluid composition intensified after the detection of subsidence at Ekofisk field in the Norwegian Continental Shelf (Hermansen et al. 2000; Nagel 2001). A key research question had been to find how the mechanical chalk properties were affected by aqueous chemistry, with focus on elastic stiffness, plastic strength and time-dependent creep rates (Risnes 2001; Hellmann et al. 2002a, b; Risnes et al. 2003; Korsnes et al. 2006a, b, 2008; Madland et al. 2008, 2011; Megawati et al. 2011, 2013; Neveux et al. 2014a, b).

Until now, most rock-mechanical studies have concentrated on water wet and water-saturated systems. It has been shown that the surface-active divalent ions, such as magnesium $\left(\mathrm{Mg}^{2+}\right)$ and sulphate $\left(\mathrm{SO}_{4}{ }^{2-}\right)$, have a huge effect on the mechanical behaviour. Heggheim et al. (2005) observed that $\mathrm{SO}_{4}{ }^{2-}$ ions in the injected synthetic seawater (SSW) brine led to a reduced yield strength than during the injection of a brine with a lower or zero $\mathrm{SO}_{4}{ }^{2-}$ ion concentration and caused weakening of chalk at lowered effective stresses. Korsnes et al. (2008) observed the same effect by demonstrating that while flooding SSW containing $\mathrm{SO}_{4}{ }^{2-}$ ions through chalk, it yielded at significantly lower stress compared to samples flooded by SSW without $\mathrm{SO}_{4}{ }^{2-}$ ions. Megawati et al. (2011) argued that the reduction in yield strength was due to its adsorption on the charged calcite surface, which led to disjoining pressure at grain-grain contacts causing pore collapse failure at lower stresses.

When magnesium chloride $\left(\mathrm{MgCl}_{2}\right)$ brine is injected through chalk, dissolution of calcite $\mathrm{CaCO}_{3}$ and precipitation of magnesite $\mathrm{MgCO}_{3}$ occur (Madland et al. 2011; Nermoen et al. 2015; Zimmermann et al. 2015; Minde et al. 2017, 2018a, b; Andersen et al. 2018). These dissolution/precipitation processes lead to enhanced bulk volume creep rates in chalk compared to when flooded with weakly reactive sodium chloride $(\mathrm{NaCl})$ brine (Madland et al. 2009, 2011). Further, Nermoen et al. (2015) showed that the bulk volume compaction rate increased when the injection rate increased, explained by the increased calcite dissolution and $\mathrm{Mg}$-bearing mineral precipitation rates. The solid volume changed because the sample lost mass and the mineral density increased (density of magnesite is $3.0 \mathrm{~g} / \mathrm{cm}^{3}$ and calcite $2.7 \mathrm{~g} / \mathrm{cm}^{3}$ ). The solid volume changes were shown to correlate to a reduction in bulk volume and the grains unlocked and reorganised causing the pore volume to reduce. $\mathrm{Mg}^{2+}$ ions have also shown to adsorb on the calcite surface leading to desorption of calcium ions (Ahsan and Fabricius 2010; Alam et al. 2010; Nermoen et al. 2018).

It has also been suggested that chemical reactions between the injected non-equilibrium brines and chalk surface lead to additional oil recovery (Hiorth et al. 2010) 
either due to rock dissolution or change in the surface charge during brine injection that affects rock wettability. For chemical reactions to play a role in enhancing the oil recovery, they must be able to mobilise oil after the initial displacement. This idea was tested in a recent study by Sachdeva et al. (2019). Here, however, no oil was produced during tail-end oil production through $\mathrm{MgCl}_{2}$ flow even though chemical reactions and pore volume compaction occurred.

Megawati et al. (2015) and Andersen et al. (2018) studied five different chalk types and found a dependence of the non-carbonate content on how the mechanical creep behaviour was affected by $\mathrm{MgCl}_{2}$ brine injection. They grouped the five outcrop chalks into groups of pure (Mons and Stevns Klint) and impure (Liège, Aalborg and Kansas) chalks with regard to the calcite content and found that $\mathrm{MgCl}_{2}$ injection into impure chalks led to an immediate increased creep rate. However, for pure chalks the increased creep rate response was delayed by a time lag of several weeks.

These rock samples were never exposed to oil, which enabled the aqueous solution to contact the minerals directly. A question that has been raised is to which extent these results are applicable to actual chalk reservoirs. Chalk wettability has been studied extensively to understand how different wetting states affect multiphase fluid flow with focus on oil recovery (Standnes and Austad 2000a, b; Zhang and Austad 2005; Strand et al. 2007). In the present study, we also focus on the mechanical stiffness, strength and creep rate dependencies upon brine injection into wettability-altered chalk, besides oil recovery.

Sachdeva et al. (2019) studied how wettability affected the mechanical behaviour of Kansas outcrop chalk saturated by oil-water mixture. It was found that the elastic stiffness and plastic strength were higher for mixed wet samples compared to water wet samples, and as $\mathrm{MgCl}_{2}$ brine was injected, the ongoing rock-fluid interactions led to enhanced creep rates, applicable for both water wet and mixed wet samples. However, after the initial oil displacement during the first 2-3 pore volumes (PVs) injected, no additional oil was produced even though chemical reactions from the rock-fluid interactions took place. Further, ongoing pore volume compaction also did not mobilise any additional oil from the samples.

This study shares the same objective as Sachdeva et al. (2019), but here we perform experiments on Mons chalk with a calcite concentration that is higher than Kansas (Andersen et al. 2018). Kansas chalk has a higher degree of contact cement than Mons chalk, which is reflected in its higher induration (Henriksen et al. 1999) compared to induration of Mons (Voake et al. 2019).

The premise of this study was to alter the wettability, test the reproducibility in the wettability alteration, document the relation between wettability and stiffness, strength and time-dependent mechanical behaviour, and finally to determine how tail-end oil recovery is affected by compaction and continuous flow of reactive brine. The wetting state of Mons chalk cores was altered to a mixed wet state prior to mechanical testing at high effective stresses and $130{ }^{\circ} \mathrm{C}$ temperature. The results from how wettabilityaltered Mons chalk responded to $\mathrm{MgCl}_{2}$ injection are compared to those carried out on Kansas chalk by Sachdeva et al. (2019).

This study emphasises on how differences in the initial pore fluid saturations and wettability affect the mechanical response of Mons chalk. The bulk, solid and pore volumes as well as oil and water volumes are monitored continuously to observe how the volume dependencies are linked to deformations and injection of reactive $\mathrm{MgCl}_{2}$ brine. 


\section{Materials and Methods}

\subsection{Rock Sample Material}

Chalk samples from a single block obtained from the Trivières Formation in Mons (Belgium) were used. This chalk belongs to Late Cretaceous age and is very pure (>99 wt\% calcite).

Ten cylindrical samples were cored, radially adjusted to $38.1 \mathrm{~mm}$ diameter, cut at desired lengths and dried at $110{ }^{\circ} \mathrm{C}$ overnight before dry mass was measured. The samples were then vacuumed and saturated by distilled water (DW) to measure saturated mass. The mass difference between the dry and saturated sample was used to estimate pore volume and saturation porosity (Table 1).

The samples were divided into two test series:

- Six samples were used for wettability determination. Three samples were kept water wet and $100 \%$ water saturated (Mww) for reference, and the other three were wettability-altered (Mmw) (Table 1).

- Four samples were used in triaxial test programme (M1 to M4). Two samples were kept water wet and $100 \%$ water saturated, and the other two were wettability-altered (Table 1).

\subsection{Description of Fluids}

Four brine compositions were used. In the wettability determination programme, two different versions of artificial seawater were used: SW1T brine contained sulphate $\left(\mathrm{SO}_{4}{ }^{2-}\right)$ and thiocyanate $\left(\mathrm{SCN}^{-}\right)$tracer, while SW0T did not (Table 2). The total dissolved solids of SW1T and SW0T were equal to synthetic sea water (SSW). The two other brines used during the triaxial test programme (Table 2) were:

Table 1 Basic properties of samples used for wettability determination and triaxial tests

\begin{tabular}{|c|c|c|c|c|c|c|c|c|}
\hline Core ID & $\begin{array}{l}\text { Wetting } \\
\text { state }\end{array}$ & $\begin{array}{l}\text { Core } \\
\text { length } \\
(\mathrm{mm})\end{array}$ & $\begin{array}{l}\text { Core } \\
\text { diameter } \\
(\mathrm{mm})\end{array}$ & $\begin{array}{l}\text { Dry mass } \\
(\mathrm{g})\end{array}$ & $\begin{array}{l}\text { Saturated } \\
\text { mass }(\mathrm{g})\end{array}$ & $\begin{array}{l}\text { Pore } \\
\text { volume } \\
(\mathrm{ml})\end{array}$ & $\begin{array}{l}\text { Bulk } \\
\text { volume } \\
(\mathrm{ml})\end{array}$ & $\begin{array}{l}\text { Saturation } \\
\text { porosity } \phi \\
(\%)\end{array}$ \\
\hline \multicolumn{9}{|c|}{ Wettability determination programme } \\
\hline Mww1 & Water wet & 72.4 & 38.1 & 126.7 & 162.1 & 35.4 & 82.5 & 42.9 \\
\hline Mww2 & & 69.9 & 38.1 & 122.3 & 156.5 & 34.2 & 79.7 & 42.9 \\
\hline Mww3 & & 73.2 & 38.1 & 130.2 & 165.4 & 35.2 & 83.5 & 42.2 \\
\hline Mmw1 & Mixed wet & 72.4 & 38.1 & 123.9 & 159.3 & 35.4 & 82.5 & 42.9 \\
\hline Mmw2 & & 68.9 & 38.1 & 122.1 & 156.3 & 34.2 & 78.6 & 43.5 \\
\hline Mmw3 & & 69.4 & 38.1 & 120.9 & 155.0 & 34.1 & 79.1 & 43.1 \\
\hline \multicolumn{9}{|c|}{ Triaxial test programme } \\
\hline M1 & Water wet & 72.7 & 38.1 & 129.4 & 164.4 & 35.0 & 82.9 & 42.2 \\
\hline M2 & & 68.9 & 38.1 & 119.9 & 153.8 & 33.9 & 78.6 & 43.2 \\
\hline M3 & Mixed wet & 68.9 & 38.1 & 119.7 & 153.7 & 34.0 & 78.6 & 43.3 \\
\hline M4 & & 68.8 & 38.1 & 122.0 & 155.0 & 33.0 & 78.4 & 42.1 \\
\hline
\end{tabular}


Table 2 Composition of brines used in the wettability determination programme and for core flooding in the triaxial test programme

\begin{tabular}{|c|c|c|c|c|}
\hline \multirow[t]{2}{*}{ Ions } & \multicolumn{2}{|c|}{$\begin{array}{l}\text { Wettability } \\
\text { determination } \\
\text { programme }\end{array}$} & \multicolumn{2}{|c|}{ Triaxial test programme } \\
\hline & $\begin{array}{l}\text { SW0T } \\
\mathrm{mol} / 1\end{array}$ & $\begin{array}{l}\text { SW1T } \\
\mathrm{mol} / 1\end{array}$ & $\begin{array}{l}1.1 \mathrm{M} \mathrm{NaCl} \\
\mathrm{mol} / 1\end{array}$ & $\begin{array}{l}0.219 \mathrm{M} \mathrm{MgCl}_{2} \\
\mathrm{~mol} / \mathrm{l}\end{array}$ \\
\hline $\mathrm{HCO}_{3}^{-}$ & 0.002 & 0.002 & 0 & 0 \\
\hline $\mathrm{Cl}^{-}$ & 0.583 & 0.492 & 1.1 & 0.438 \\
\hline $\mathrm{SO}_{4}^{2-}$ & 0 & 0.024 & 0 & 0 \\
\hline $\mathrm{SCN}^{-}$ & 0 & 0.024 & 0 & 0 \\
\hline $\mathrm{Mg}^{2+}$ & 0.045 & 0.045 & 0 & 0.219 \\
\hline $\mathrm{Ca}^{2+}$ & 0.013 & 0.013 & 0 & 0 \\
\hline $\mathrm{Na}^{+}$ & 0.460 & 0.393 & 1.1 & 0 \\
\hline $\mathrm{Li}^{+}$ & 0 & 0.024 & 0 & 0 \\
\hline $\mathrm{K}^{+}$ & 0.010 & 0.034 & 0 & 0 \\
\hline Ionic strength & 0.643 & 0.647 & 1.1 & 0.657 \\
\hline TDS (g/l) & 33.39 & 33.39 & 64.28 & 44.52 \\
\hline
\end{tabular}

- $1.1 \mathrm{M} \mathrm{NaCl}$ brine for initial saturation to resemble resident formation fluids. $\mathrm{NaCl}$ brine moderately interacts with chalk (Madland et al. 2011; Ricci et al. 2013; Hofmann et al. 2016).

- $0.219 \mathrm{M} \mathrm{MgCl}_{2}$ brine used as a flooding brine with equal ionic strength as seawater. This is injected to trigger dissolution/precipitation effects from the $\mathrm{Ca}-\mathrm{Mg}$ exchange (Madland et al. 2009, 2011) and adsorption effects of magnesium ions on the calcite surface (Ahsan and Fabricius 2010; Alam et al. 2010; Nermoen et al. 2018; Liu et al. 2018).

A $60-40 \%$ volume mixture of crude oil from the Heidrun field offshore Norway and heptane was used. The acid number of the Heidrun oil was measured to be $2.82 \mathrm{mg} \mathrm{KOH} / \mathrm{g}$, while the acid number of the oil mixture was $2.12 \mathrm{mg} \mathrm{KOH} / \mathrm{g}$ measured according to the Fan and Buckley (2007) procedure.

\subsection{Wettability Alteration and Fluid Saturations}

Five samples (three for wettability determination and two for triaxial tests) were wettability-altered according to the following procedure wherein the samples were:

- Saturated by $1.1 \mathrm{M} \mathrm{NaCl}$ brine.

- Mounted in a Hassler cell and heated to $50{ }^{\circ} \mathrm{C}$. Flooded two pore volumes (PVs) of the oil mixture in each direction during which the produced brine was collected to estimate the initial water saturation $S_{\mathrm{wi}}$.

- Submerged the samples in the same oil mixture in ageing containers and left for 21 days at $90{ }^{\circ} \mathrm{C}$.

The wettability-altered samples were termed Mmw1 to Mmw3 in the wettability determination programme and M3 and M4 in the triaxial test programme. Five more samples were kept water wet and were simply saturated by $1.1 \mathrm{M} \mathrm{NaCl}$ brine. The samples Mww1 
to Mww3 were used in the wettability determination programme and M1 and M2 were used in the triaxial test programme.

\subsection{Chromatographic Separation for Wettability Determination}

The chromatographic separation technique for wettability determination used here, and developed by Strand et al. (2006a), refers to how the effluent concentration profile of nonaffine tracers differ from that of surface-active ions. The surface-active divalent $\mathrm{SO}_{4}{ }^{2-}$ ions replace the monovalent anions on the positively charged calcite surface sites. Sulphate adsorption occurs on mineral surface areas in contact with water; hence, a key premise is that mineral surfaces covered by oil will not capture the injected $\mathrm{SO}_{4}{ }^{2-}$ ions. By coinjecting $\mathrm{SO}_{4}{ }^{2-}$ and non-affine thiocyanate $\left(\mathrm{SCN}^{-}\right)$tracer ions, after being flooded by a brine stripped of these ions, the two effluent concentration profiles split as the increased concentration of the adsorbed ion is delayed compared to the non-affine tracer. The split, measured by the area spanned by the two concentration profiles, as a function of pore volumes (PVs) injected is proportional to the mineral surface in contact with water. When oil is bound to calcite mineral surfaces in mixed wet samples, the separation area is reduced compared to water wet samples if the specific surface area is the same. The ratio of areas for mixed wet sample $\left(A_{\mathrm{mw}}\right)$ and water wet sample $\left(A_{\mathrm{ww}}\right)$ defines the wettability index $\left(W_{\mathrm{i}}\right)$,

$$
W_{\mathrm{i}}=\frac{A_{\mathrm{mw}}}{A_{\mathrm{ww}}}
$$

A wettability index of 1 implies that the sample has the same number of surface sites for sulphate adsorption as the reference case, making it $100 \%$ water wet. A $W_{\mathrm{i}}$ of zero (overlapping sulphate and tracer curves) implies no sulphate adsorption making the sample $100 \%$ oil wet. Other values of $W_{\mathrm{i}}$ imply that the minerals are partially covered by oil (mixed wet). Rock-fluid interactions also change the specific surface area. Dissolution and precipitation reactions can increase or decrease the specific surface area, thereby changing the number of surface sites even when oil is present, hence leading to a mixed wet state.

\subsection{Quantifying the Wettability Alteration by Ageing}

The wettability alteration procedure was equivalent for all samples in both the 'wettability determination programme' and 'triaxial test programme'. Wettability determination could not be done on samples for the triaxial tests because the flow of fluids used to determine wettability displaces oil and alters the wettability, since sulphate has shown to modify wettability (Strand et al. 2006b; Zhang and Austad 2006; Zhang et al. 2007). We assume that the wettability determined for the three aged cores in the wettability determination programme is the same as the two aged cores in the triaxial test programme.

Wettability determination was performed in a Hassler cell by (1) flooding four PVs of SW0T brine, (2) injecting SW1T brine for $500 \mathrm{~min}$ with a flow rate of $0.2 \mathrm{ml} / \mathrm{min}$. During the SW1T injection, 40 samples were collected using a Gilson fraction sampler. Each sample contained $2 \mathrm{ml}$ of fluids collected over $10.0 \mathrm{~min}$ with $2.5 \mathrm{~min}$ between each sample. For each fluid sample, the thiocyanate and sulphate concentrations were determined using ion chromatography (IC). The concentration $c_{k}$ of each species $k\left(\mathrm{SCN}^{-}\right.$and $\left.\mathrm{SO}_{4}{ }^{2-}\right)$ is rescaled by the $\mathrm{SCN}^{-}$and $\mathrm{SO}_{4}{ }^{2-}$ concentrations of SW0T $c_{k 0}$ (in this case zero) and SW1T $c_{k 1}=0.024 \mathrm{~mol} / \mathrm{litre}$, such that a reduced concentration $\hat{C}_{k}$ could be obtained, 


$$
\widehat{C_{k}}=\frac{c_{k}-c_{k 0}}{c_{k 1}-c_{k 0}}
$$

This reduced concentration varies between zero and one, and when the effluent concentration equals the inlet concentration, $\widehat{c_{k}}=1$ enabling the thiocyanate and sulphate curves to be plotted together. The area between the curves was estimated by integration using the trapeze method. Further, larger cores will have a larger total surface area than smaller ones, so the areas are reported in per gram of the core for accurate comparison (Table 3).

\subsection{Ion Chromatography (IC)}

The effluent samples acquired were diluted 500 times with nanopure water (of specific resistance $18.2 \mathrm{M} \Omega-\mathrm{cm}$ at $25^{\circ} \mathrm{C}$ ) to meet the linear regime of the Dionex IC S-5000+ Ion Chromatography System. The samples were diluted using the Gilson GX-271 liquid handler operated by the Trilution software. Once the IC analysis finalised, a series of peaks, corresponding to each ion in the effluent sample, was obtained. The area under each peak was assumed to be proportional to the ion concentration in the fluid, when compared to known standards with known concentrations.

\subsection{The Triaxial Cell Set-up for Mechanical Flow-Through Tests}

The samples were mounted into the triaxial cell allowing for continuous measurements of axial and radial strains at elevated stresses and temperature (Fig. 1). The triaxial cell was equipped with a heating element and a regulating system with temperature control $\left(0.1{ }^{\circ} \mathrm{C}\right.$ precision). Three pumps were used to control the axial piston pressure $\left(P_{\text {pist }}\right)$, confining pressure $\left(\sigma_{\text {rad }}\right)$ and flow rate $(Q)$. The pore pressure $\left(P_{\mathrm{p}}=0.7 \mathrm{MPa}\right)$, was controlled by a back-pressure regulator ensuring constant pore pressure on the downstream side. An external linear variable differential transducer (LVDT), placed on top of the moving piston, monitored the change in sample length $(L)$ and an internal extensometer monitored the change in diameter $(D)$.

Table 3 Estimated integrated areas per gram of the core for water wet and mixed wet samples, and the corresponding wettability indexes

\begin{tabular}{|c|c|c|c|c|}
\hline Core & $\begin{array}{l}\text { Estimated area between } \\
\text { sulphate and tracer (PV) }\end{array}$ & $\begin{array}{l}\text { Integrated sulphate-tracer } \\
\text { area per gram core }\left(10^{-3}\right. \\
\mathrm{PV} / \mathrm{g})\end{array}$ & Wettability index $\left(W_{\mathrm{i}}\right)$ & $\begin{array}{l}\text { Irreducible } \\
\text { water saturation } \\
\left(S_{\mathrm{wi}}\right)\end{array}$ \\
\hline
\end{tabular}

Water wet

$\begin{array}{lllll}\text { Mww1 } & 0.201 & 1.59 & 1 & - \\ \text { Mww2 } & 0.175 & 1.43 & 1 & - \\ \text { Mww3 } & 0.184 & 1.41 & 1 & \\ \text { Average } & 1.48 \pm 0.08 & & \\ \text { Mixed wet } & & & 0.31 \\ \text { Mmw1 } & 0.112 & 0.88 & 0.60 \pm 0.03 & 0.38 \\ \text { Mmw2 } & 0.114 & 0.93 & 0.63 \pm 0.03 & 0.37 \\ \text { Mmw3 } & 0.118 & 0.98 & 0.66 \pm 0.04 & \\ \text { Average } & & 0.93 \pm 0.04 & 0.63 \pm 0.07 & \end{array}$




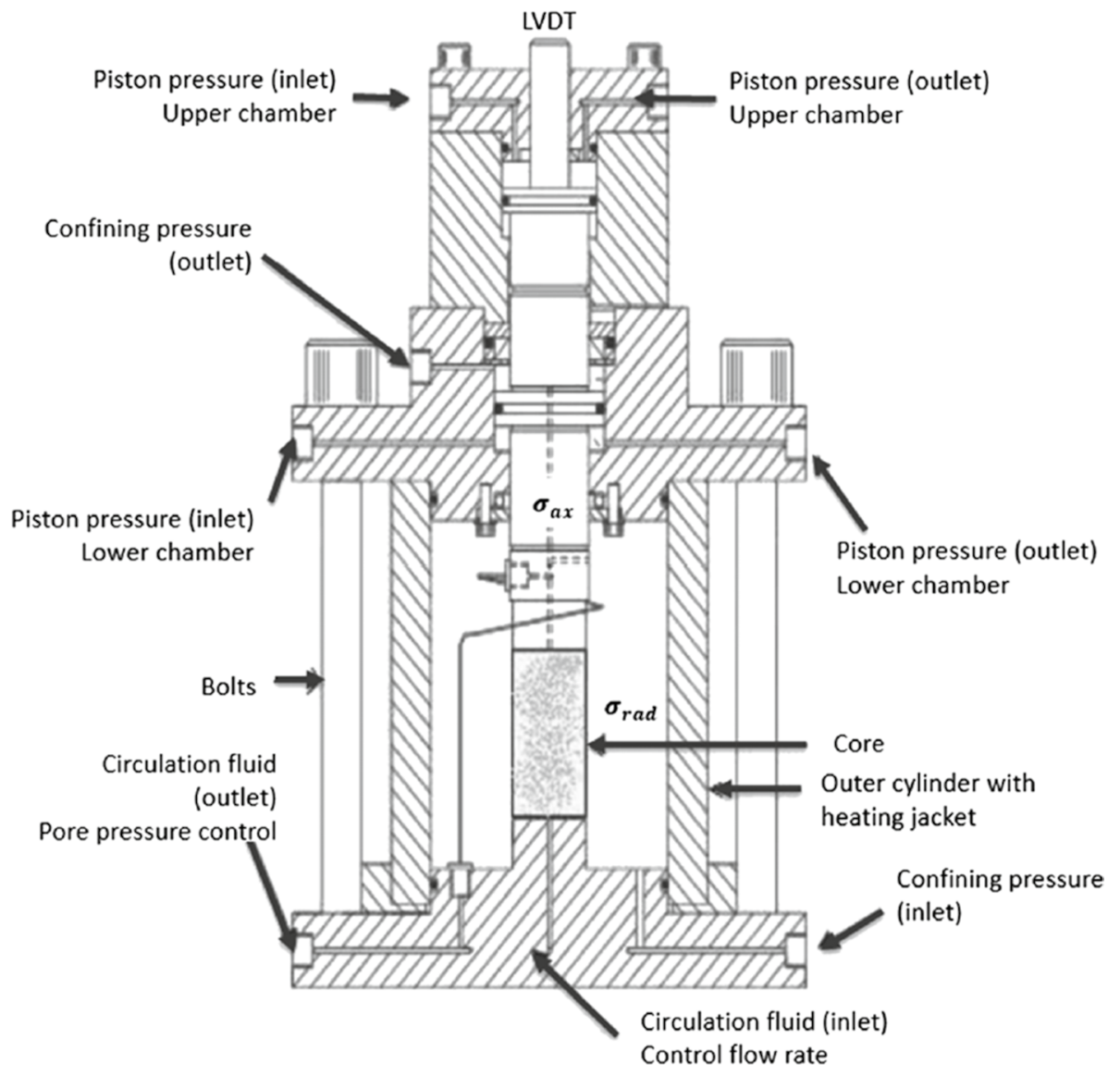

Fig. 1 Sketch of the triaxial cell

The axial stress was calculated using radial stress, piston pressure, frictional pressure of the piston movement in the triaxial cell and an area factor $\left(f_{\text {area }}=1.28\right)$ for the piston pressure chamber and the cross-area of the plug,

$$
\sigma_{\mathrm{ax}}=\sigma_{\text {rad }}+f_{\text {area }}\left(P_{\text {pist }}-P_{\text {fric }}\right)
$$

In the hydrostatic phase, the stresses are equal in all directions, so the bulk modulus $K$ is given by,

$$
K=\Delta \sigma_{\mathrm{ax}}^{\prime} / \Delta \varepsilon_{\mathrm{vol}}
$$

here $\Delta \sigma_{\mathrm{ax}}^{\prime}$ is the change in effective stress in axial direction and $\Delta \varepsilon_{\mathrm{vol}}$ is the change in volumetric strain (see Eq. 7). The effective stress is given by the imposed stress in a spatial direction minus a fraction $\alpha$ times the pore pressure $\left(\sigma^{\prime}=\sigma-\alpha P_{\text {pore }}\right)$. We assume the Biot coefficient $\alpha=1$ hereon. 


\subsection{Constitutive Equations}

The bulk, pore and solid volumes are linked through the constitutive equation $V_{\mathrm{b}}=V_{\mathrm{s}}+V_{\mathrm{p}}$. During the test, the pore volume is not directly measured. Since porosity is determined by the ratio of pore volume $\left(V_{\mathrm{p}}\right)$ to bulk volume $\left(V_{\mathrm{b}}\right)$,

$$
\phi=\frac{V_{\mathrm{p}}}{V_{\mathrm{b}}}=1-\frac{V_{\mathrm{s}}}{V_{\mathrm{b}}}
$$

the solid volume $\left(V_{\mathrm{s}}\right)$, estimated from the IC analysis, and the bulk compaction can be used to estimate porosity evolution using (Nermoen et al. 2015),

$$
\phi(t)=\frac{\phi_{\mathrm{o}}+\varepsilon_{\mathrm{vol}}-\Delta V_{\mathrm{s}} / V_{\mathrm{b}, \mathrm{o}}}{1+\varepsilon_{\mathrm{vol}}}
$$

where $\phi(t)$ is the porosity at time $t, \phi_{\mathrm{o}}$ is the original porosity, $\varepsilon_{\mathrm{vol}}$ is the volumetric strain, $\Delta V_{\mathrm{s}}$ is the change in the solid volume, and $V_{\mathrm{b}, \mathrm{o}}$ defines the original bulk volume.

\subsection{Evolution in Bulk Volume with Time}

The radial strain was measured only at the middle of the core. Since radial deformation is non-equal along the length of the cores even in hydrostatic tests (Nermoen et al. 2015), we introduced the factor $X$, assumed to be constant throughout the test, to improve volumetric strain estimates from axial strain measurements,

$$
\varepsilon_{\mathrm{vol}}=X \varepsilon_{\mathrm{ax}}
$$

The factor $X$ was determined from the ratio of length and volume changes measured with a sliding caliper directly on the core sample after test. As such, the bulk volume can be estimated via,

$$
V_{\mathrm{b}, t}=V_{\mathrm{b}, \mathrm{o}}\left(1-\varepsilon_{\mathrm{vol}}\right)=V_{\mathrm{b}, \mathrm{o}}\left(1-X \varepsilon_{\mathrm{ax}}\right)
$$

\subsection{Evolution in Solid Volume with Time}

The solid mass evolution over time $M_{\mathrm{s}}(t)$ is calculated from the difference in the concentrations of the injected fluid and the produced effluent fluids (from ion chromatography) times the flow rate $q_{\text {in }}$ and molar mass of $\mathrm{Mg}$ and Ca $\left(n_{\mathrm{Mg}}=24 \mathrm{~g} / \mathrm{mol}\right.$ and $n_{\mathrm{Ca}}=40 \mathrm{~g} /$ mol),

$$
M_{\mathrm{s}}(t)=M_{\mathrm{s}, 0}+\eta \int_{0}^{t} q_{\text {in }}\left(n_{\mathrm{Mg}}\left(c_{\text {in, } \mathrm{Mg}}-c_{\text {out }, \mathrm{Mg}}\right)-n_{\mathrm{Ca}}\left(c_{\text {in }, \mathrm{Ca}}-c_{\text {out }, \mathrm{Ca}}\right)\right) \mathrm{d} t
$$

This is used to interpolate between the measured mass before and after test, and $\eta$ is a fitting parameter that makes the observed replacement of $\mathrm{Ca}$ by $\mathrm{Mg}$ from IC data match the observed mass loss (measured on a scale) in dry weight. 
The solid density is measured before and after test, and we used the calcium produced from the sample $m_{\mathrm{Ca}}(t)$, at time $t$ to interpolate between the initial $\left(\rho_{\mathrm{s}, \mathrm{O}}\right)$ and final $\left(\rho_{\mathrm{s}, \mathrm{f}}\right)$ densities via,

$$
\rho_{\mathrm{s}}(t)=\rho_{\mathrm{s}, \mathrm{o}}+\left(\left(\rho_{\mathrm{s}, \mathrm{f}}-\rho_{\mathrm{s}, \mathrm{o}}\right)\left(m_{\mathrm{Ca}}(t) / m_{\mathrm{Ca}, \mathrm{total}}\right)\right)
$$

Using Eqs. 9 and 10, the change in solid volume $\Delta V_{\mathrm{s}}$ can be estimated,

$$
\Delta V_{\mathrm{s}}(t)=\frac{M_{\mathrm{s}}(t)}{\rho_{\mathrm{s}}(t)}-\frac{M_{\mathrm{s}, \mathrm{o}}}{\rho_{\mathrm{s}, \mathrm{o}}} .
$$

\subsubsection{Evolution in Porosity and Pore Volume with Time}

The pore volume is not directly monitored in the test, so it is estimated from the bulk volume (Eq. 8) minus the solid volume (Eq. 11) using,

$$
V_{\mathrm{p}}(t)=V_{\mathrm{b}}(t)-V_{\mathrm{s}}(t)=V_{\mathrm{b}}(t)-V_{\mathrm{s}, 0}-\Delta V_{\mathrm{s}}(t)
$$

The water volume in the sample is not directly measured. So, to estimate the water volume as a function of time we use,

$$
V_{\mathrm{b}}=V_{\mathrm{p}}+V_{\mathrm{s}}=V_{\mathrm{w}}+V_{\mathrm{o}}+V_{\mathrm{s}}
$$

where $V_{\mathrm{w}}$ and $V_{\mathrm{o}}$ are the volumes of water and oil. When this equation is re-shuffled for water volume, which is the unknown parameter in this experimental design, the measured quantities, namely the bulk volume, solid volume and oil volume inside the sample, are used. The oil volume in the sample at any time is estimated from the initial oil volume minus the oil volume produced in a vertically oriented gravity glass separator. The oil $\left(S_{\mathrm{o}}\right)$ and water $\left(S_{\mathrm{w}}\right)$ saturations in the sample are then given by,

$$
S_{\mathrm{o}}(t)=\frac{V_{\mathrm{o}}(t)}{V_{\mathrm{p}}(t)} \text { and } S_{\mathrm{w}}(t)=\frac{V_{\mathrm{w}}(t)}{V_{\mathrm{p}}(t)}
$$

These equations implicitly obey the requirement that $S_{\mathrm{o}}+S_{\mathrm{w}}=1$.

\subsection{Triaxial Test programme}

The mechanical tests were performed according to the following procedure:

1. Mounted the cores in the triaxial cell with bypass valve open (no flow through the cores).

2. Simultaneously increased confining pressure $\left(\sigma_{\text {rad }}\right)$ to $1.2 \mathrm{MPa}$ and pore pressure $\left(P_{\mathrm{p}}\right)$ to $0.7 \mathrm{MPa}$.

3. Increased temperature to $130{ }^{\circ} \mathrm{C}$.

4. Increased hydrostatic stress to approximately 1.5 times yield at $0.045 \mathrm{MPa} / \mathrm{min}$ loading rate while observing volumetric strain to determine stiffness and strength. The stiffness measurements were taken during loading conditions and hereon referred to as 'bulk modulus'. 
5. Observed volumetric creep and oil production with constant pore pressure and hydrostatic stress with bypass valve open the first 15 days.

6. On the 16th creep day the bypass valve was closed and $\mathrm{MgCl}_{2}$ brine was flooded at $0.010 \mathrm{ml} / \mathrm{min}$ flow rate.

7. Increased $\mathrm{MgCl}_{2}$ brine flow rate to $0.040 \mathrm{ml} / \mathrm{min}$ after a certain number of days.

8. Decreased flow rate back to $0.010 \mathrm{ml} / \mathrm{min}$.

9. Cleaned the cores with four PVs of DW at the end of the test.

10. Decreased temperature to room temperature. Used toluene to remove leftover oil from cores M3 and M4, followed by methanol flooding to remove toluene. Multiple iterations of toluene and methanol flooding were performed until effluent became completely transparent in colour.

11. Used DW to remove methanol from these cores.

12. Chromatographic separation tests were performed on all four samples.

13. Demounted cores from the triaxial cell and measured saturated mass. Kept them in an oven at $110{ }^{\circ} \mathrm{C}$ overnight.

14. Measured dry weights, lengths and diameters the day after.

15. Cut the cores into 6 sections of almost equal lengths. The density and specific surface area of these sections and of the unflooded end pieces were measured using gas pycnometer and Brunauer-Emmett-Teller (BET) theory (Brunauer et al. 1938), respectively.

Effluent samples were taken two to three times a week during steps 5 to 9 . The ionic composition was estimated using ion chromatography. The oil production was measured for mixed wet cores M3 and M4 using a separator on the downstream side of the triaxial cell. Due to pore pressure fluctuations during the M3 test, the oil volume measurements were disregarded because of emulsification of the produced oil. Pore volume was estimated from the solid volume estimate and bulk volume measurement. With the oil production from core M4 known, the remaining oil volume inside the core was estimated.

\subsection{Mineral Density and Specific Surface Area Determination}

The mineral density and specific surface area were estimated by gas pycnometry and Brunauer-Emmett-Teller (BET) technique, respectively.

Before the mineral density was measured, the cut sections for all samples were kept in the oven at $110{ }^{\circ} \mathrm{C}$ overnight. Next morning these sections were taken out and placed in a vacuum sealed container to cool down. Each section was weighted and inserted, one-byone, into the Micromeritics AccuPyc II 1340 Gas Pycnometer (using helium) to measure the solid volume. With mass and solid volume known, the mineral density of each section was estimated.

BET theory works by determining the adsorption of gas molecules on a solid surface. The specific surface area measurements were taken on Micromeritics TriStar II instrument using liquid nitrogen, as it does not chemically react with the chalk. Two grams of powdered chalk was added to the sample glass tube and degassed for $5 \mathrm{~h}$ at $110{ }^{\circ} \mathrm{C}$ on Micromeritics VacPrep 061 Sample Degas System. A stable vacuum pressure of 20-30 mTorr was attained for all tested samples before the sample tubes were attached to the BET apparatus. The specific surface area was measured automatically by the TriStar II 3020 software. 


\section{Results}

The experimental results are presented in the following way: (1) wettability determination programme based on 3 reference water wet and 3 mixed wet samples, (2) stiffness and strength measurements from the hydrostatic loading tests, (3) volumetric deformation during creep, (4) effluent sample analyses using ion chromatography, (5) recovery of oil from the mixed wet samples, (6) analyses of all cores used in the triaxial test programme after tests and (7) wettability by chromatographic separation tests after triaxial tests on all samples.

\subsection{Wettability Determination Based on 6 Samples}

Figure $2 \mathrm{a}, \mathrm{b}$ shows an example of two chromatographic separation tests performed on a completely water wet sample (Mww2) and a mixed wet sample (Mmw3). Here, the reduced ion concentration is plotted against PVs of SW1T flooded. Each dot represents a single effluent sample and the corresponding thiocyanate ion and sulphate ion concentrations. The separation between thiocyanate and sulphate ions can be seen. Figure $2 \mathrm{c}$ displays the difference between the thiocyanate and sulphate concentrations for the water wet sample (Mww2, blue) and mixed wet sample (Mmw3, green). The green curve has a smaller area and is shifted to the left of the blue. The integrated areas between the two curves were
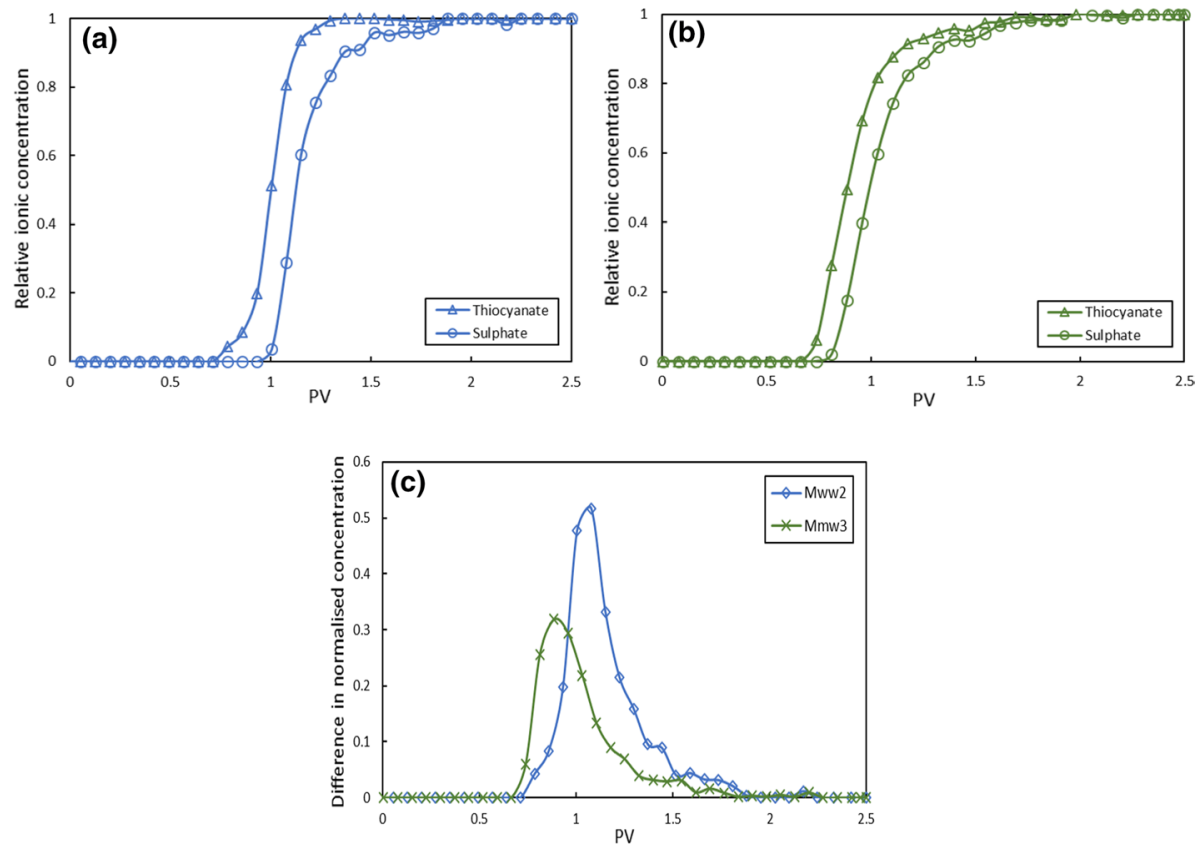

Fig. 2 Chromatographic separation on a water wet core (Mww2, blue) and b mixed wet core (Mmw3, green). The plots (a) and (b) show how the increase in sulphate concentration is delayed compared to the thiocyanate concentration after SW1T is injected. The plot (c) shows the difference in normalised concentrations between the thiocyanate and sulphate curves for the water wet (blue) and mixed wet cores (green). The integrated separation areas for Mww2 and Mmw3 were $1.43 \times 10^{-3} \mathrm{PV} / \mathrm{g}$ and $0.98 \times 10^{-3} \mathrm{PV} / \mathrm{g}$, respectively (Table 3) 

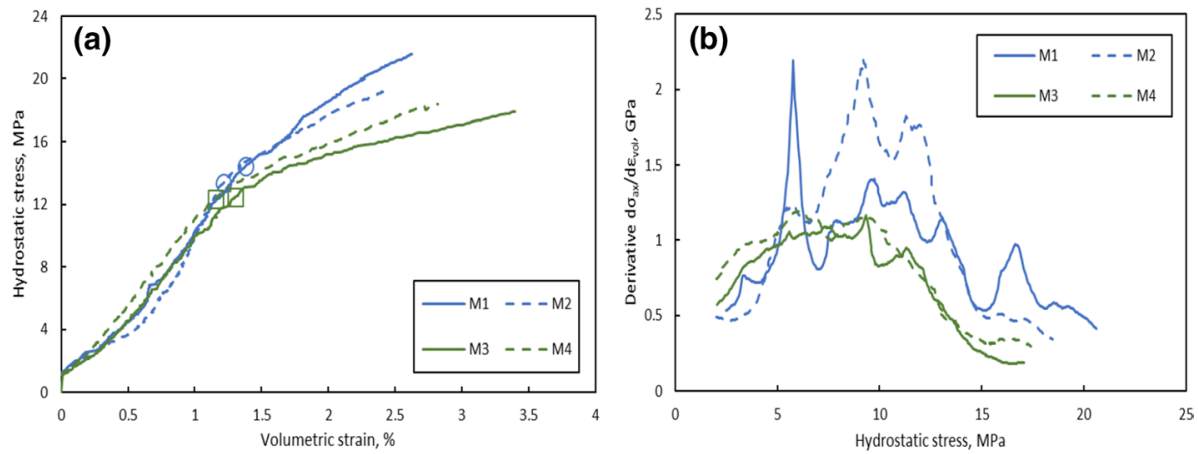

Fig. 3 a Hydrostatic stress versus volumetric strain for all samples in the triaxial test programme. Yield stresses are displayed on the curves. b Slope of stress-strain curve plotted as a function of stress. Blue and green lines represent water wet and mixed wet samples, respectively

Table 4 Bulk modulus, onset of yield stress and creep stress of M1 to M4 samples from hydrostatic loading at $130^{\circ} \mathrm{C}, 0.7 \mathrm{MPa}$ pore pressure and with the bypass kept open

\begin{tabular}{llllllll}
\hline Core & Wetting state & $\begin{array}{l}\text { Initial water } \\
\text { saturation } \\
\text { (fraction) }\end{array}$ & $\begin{array}{l}\text { Onset of } \\
\text { yield stress } \\
(\mathrm{MPa})\end{array}$ & $\begin{array}{l}\text { Creep } \\
\text { stress } \\
(\mathrm{MPa})\end{array}$ & $\begin{array}{l}\text { Bulk } \\
\text { modulus } \\
(\mathrm{GPa})\end{array}$ & $\begin{array}{l}\text { Uncertainty } \\
\text { in bulk } \\
\text { modulus } \\
\left(\times 10^{-1} \mathrm{GPa}\right)\end{array}$ & $\begin{array}{l}\text { Creep stress/ } \\
\text { yield stress } \\
\text { factor }\end{array}$ \\
\hline M1 & Water wet & 1 & 14.4 & 21.5 & 1.3 & 0.08 & 1.49 \\
M2 & & 1 & 13.4 & 19.3 & 1.8 & 0.24 & 1.44 \\
M3 & Mixed wet & 0.34 & 12.4 & 17.8 & 1.0 & 0.06 & 1.44 \\
M4 & & 0.36 & 12.3 & 18.3 & 1.1 & 0.09 & 1.49 \\
\hline
\end{tabular}

divided by the weight of the core to provide accurate comparison for differently sized cores. The average areas for water wet and mixed wet samples were $1.48 \pm 0.08 \mathrm{PV} / \mathrm{g}$ and $0.93 \pm 0.04 \mathrm{PV} / \mathrm{g}$, respectively. This corresponds to an average $W_{\mathrm{i}}$ of $0.63 \pm 0.07$ for the wettability-altered samples. The estimated areas for all samples are reported in Table 3 displaying great repeatability. The initial irreducible water saturation ranged from 0.31 to 0.38 .

It is assumed that the $W_{\mathrm{i}}$ of the mixed wet samples used in the triaxial test programme, drilled from the same block and altered in the same way, was also $0.63 \pm 0.07$.

\subsection{Stiffness and Strength Determination from Hydrostatic Loading Tests}

The volumetric strain was measured during hydrostatic loading from $1.2 \mathrm{MPa}$ to approximately 1.5 times the yield at $130{ }^{\circ} \mathrm{C}$ and $0.7 \mathrm{MPa}$ pore pressure. The onset of yield stress was determined at the point when the stress-strain curve deviated by more than $0.5 \mathrm{MPa}$ from the initial straight elastic line used to determine the loading bulk modulus $(K)$. The stress-strain curve during loading and the yield stresses for all four cores are shown in Fig. 3a, and the yield stress, bulk modulus and creep stress used further are reported in Table 4 that also displays the initial water saturation. 


\subsection{Stiffness Observations}

The loading bulk modulus was estimated from hydrostatic loading curves from 7 to $11 \mathrm{MPa}$ hydrostatic stress interval via Eq. 4 (reported in Table 4 and Fig. 3a). The bulk moduli of the water wet samples (M1 and M2) were $1.3 \mathrm{GPa}$ and $1.8 \mathrm{GPa}$, which were higher than the mixed wet samples (M3 and M4) that had stiffnesses of $1.1 \mathrm{GPa}$ and $1.0 \mathrm{GPa}$, respectively. When the loading bulk modulus was measured in three other stress intervals, 2-10 $\mathrm{MPa}$, 4-8 MPa and 4-10 MPa, the mixed wet samples M3 and M4 attained the same values (1.0 GPa and 1.1 GPa, respectively). However, the slopes in the stress-strain curves varied for the water wet samples, where M1 varied from 0.9 to $1.8 \mathrm{GPa}$ and M2 varied from 1.0 to $1.3 \mathrm{GPa}$. Thus, it cannot be claimed that the stiffness is significantly altered by the ageing procedure and wettability alteration. This is emphasised in Fig. 3b where the slopes of the stress-strain curves obtained in $\pm 0.5 \mathrm{MPa}$ interval are plotted against the hydrostatic stresses. Here, the variation in slope during loading is displayed. Stiffness estimates during loading are imprecise as the slope shows significant changes before the samples reach their yield stresses. These yield stresses, however, can potentially be interpreted with greater certainty as seen in Fig. $3 \mathrm{~b}$ where the slope decreases systematically for all samples.

\subsection{Strength Observations}

The yield stresses for all cores are reported in Table 4 and shown on the loading curves in Fig. 3. The water wet cores (M1 and M2) yielded at $13.90 \pm 0.50 \mathrm{MPa}$, while the mixed wet cores (M3 and M4) yielded at $12.35 \pm 0.05 \mathrm{MPa}$. The yield stresses were also measured using the same elastic regions defined in the 'Stiffness observations' and were found to be varying in a range of $\pm 1 \mathrm{MPa}$. Even though the numbers obtained suggest that the water wet samples are stronger than the mixed wet samples, we cannot claim the differences observed to be significant since the uncertainty of the experimental method and interpretation is beyond or in the same range as the differences. Hence, the yield strength of water wet and mixed wet samples was found to be not significantly different. Figure 4 shows the relationship between strength and stiffness based on the data reported in Table 4.

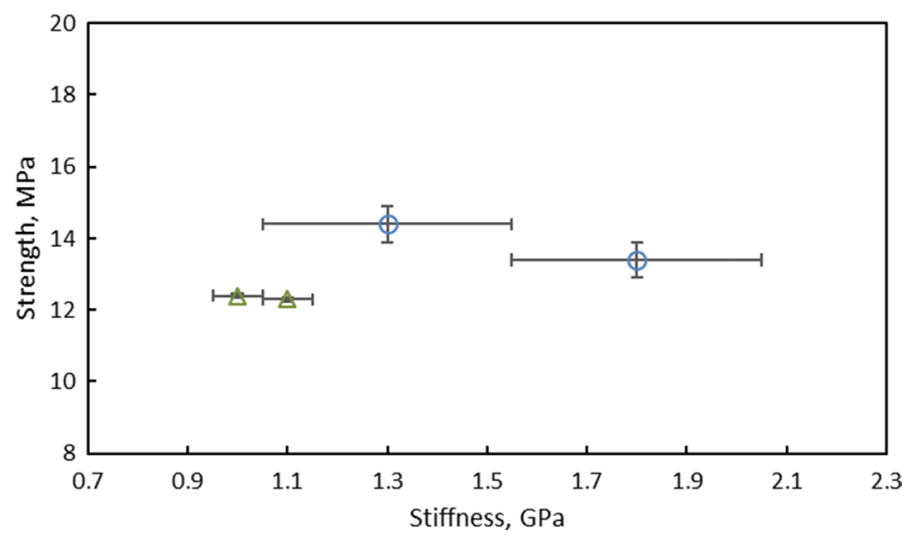

Fig. 4 Plastic strength (onset of yield) versus stiffness (bulk modulus). The blue circles and green triangles denote water wet and mixed wet samples, respectively 


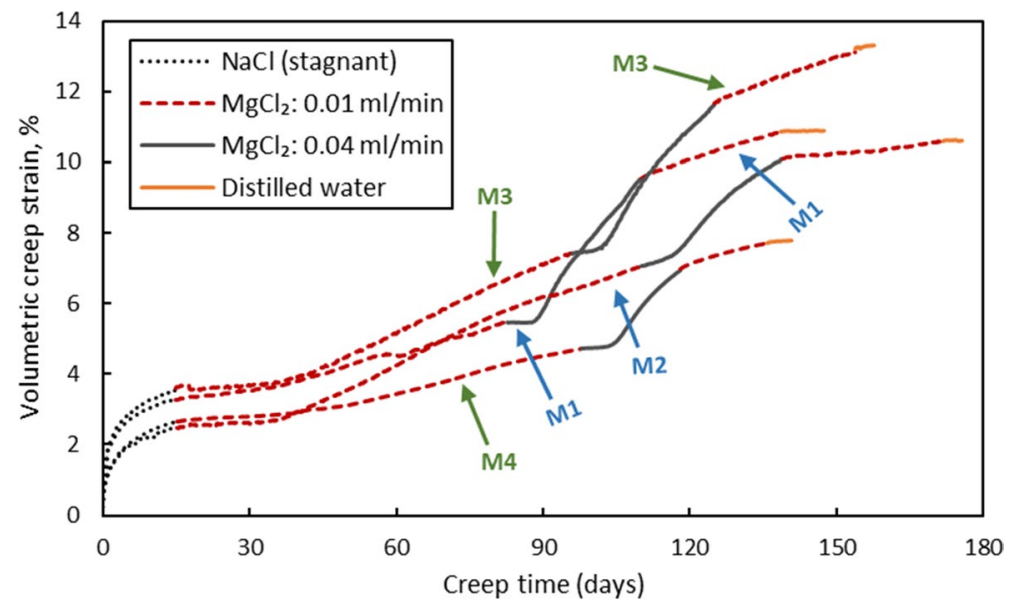

Fig. 5 Volumetric creep strain with time for $100 \%$ brine-saturated water wet cores M1 and M2 (blue arrows), and oil and brine-saturated mixed wet cores M3 and M4 (green arrows)

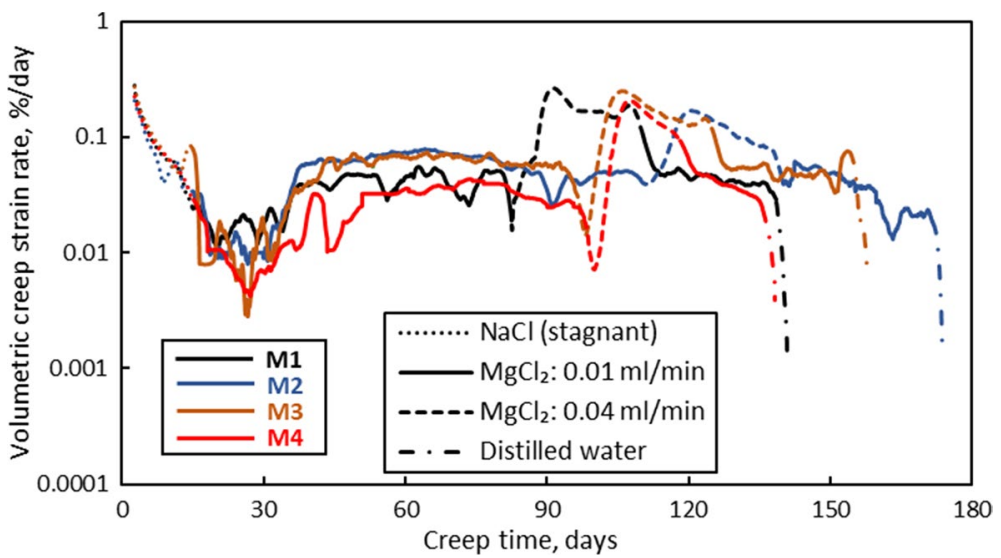

Fig. 6 Volumetric creep strain rate with time for $100 \%$ brine-saturated water wet cores M1 (black) and M2 (dark blue), and oil and brine-saturated mixed wet cores M3 (brown) and M4 (red). The different brines are shown by a dotted lines for $\mathrm{NaCl}$ brine, $\mathbf{b}$ solid lines for $\mathrm{MgCl}_{2}$ brine at a flow rate of $0.010 \mathrm{ml} / \mathrm{min}, \mathbf{c}$ dashed lines for $\mathrm{MgCl}_{2}$ brine at a flow rate of $0.040 \mathrm{ml} / \mathrm{min}$, and $\mathbf{d}$ dash-dotted lines for DW

\subsection{Volumetric Deformation During Creep}

The creep stress was set to approximately 1.5 times yield stress. Since the yield stress was determined by naked eye during loading, the actual creep stresses deviated from the 1.5 factor when the yield stress was determined systematically. A variation between a factor of 1.44 and 1.49 times yield stress was used (Table 4). The creep strains and creep strain rates are shown in Figs. 5 and 6, respectively, for all four cores. The volumetric creep strain for different wettability cores followed a similar trend during the stagnant fluid creep period (black dotted lines in Fig. 5 and all dotted lines in Fig. 6). At the start of $\mathrm{MgCl}_{2}$ flow at a rate of $0.010 \mathrm{ml} / \mathrm{min}$, we observe that the strain rate decreased for approximately 15 days 
before an acceleration phase is observed for all cores (red dashed lines in Fig. 5 and all solid lines in Fig. 6). Further, the creep curves for the water wet core M2 and the mixed wet core M3 were almost parallel (Fig. 5). These two had a saturation porosity before test of $43.2 \%$ and $43.3 \%$, respectively. The two other curves for the samples M1 and M4, with a porosity of $42.2 \%$ and $42.1 \%$, respectively, were also parallel. This indicates how porosity can influence the mechanical properties and further that the chalk mechanical behaviour of Mons chalk is independent of the presence of oil in the cores. After increasing the flow rate four times to $0.040 \mathrm{ml} / \mathrm{min}$ in all cores, accelerated strain was observed for all cores after a delay of 5-10 days (dark grey solid lines in Fig. 5 and dashed lines in Fig. 6).

Afterwards, the flow rate was reduced to $0.010 \mathrm{ml} / \mathrm{min}$, which led to an immediate reduction in strain rate for all cores. The strain rate for all cores dropped to the original value obtained during the first flooding period at $0.010 \mathrm{ml} / \mathrm{min}$.

Before demounting, all cores were flooded by DW to remove any salts. This led to a sudden drop in the creep rate for all samples (orange solid lines in Fig. 5 and dash-dotted lines in Fig. 6). Even though the exact creep rates differed, the response to any changes in brine composition and flow rates was the same. The final volumetric creep strains at the end of the tests for cores M1 to M4 are 10.9\% (after 147.5 creep days), 10.6\% (after 175.7 creep days), $13.3 \%$ (after 157.7 creep days) and 7.8\% (after 141.8 creep days), respectively.

\subsection{Effluent lon Concentration During $\mathrm{MgCl}_{2}$ Brine Flow}

Rock-fluid interactions change the ion concentration of the effluent brine. Effluents were sampled two to three times per week during creep phase. The ion concentrations of the two most important ions, calcium and magnesium, for the water wet (M1 and M2) and mixed wet (M3 and M4) cores are shown in Fig. 7.

In all four plots in Fig. 7, the magnesium concentration decrease compared to the injected concentration. This is a result of adsorption of magnesium ions on the mineral surface and desorption of calcium ions, and precipitation of magnesium-bearing mineral phases and dissolution of calcium carbonate (Madland et al. 2011; Nermoen et al. 2015; Zimmermann et al. 2015; Minde et al. 2017, 2018a, b; Andersen et al. 2018; Sachdeva et al. 2019).

From 15 days onwards when $\mathrm{MgCl}_{2}$ brine flow started, a transient period in the calcium production and magnesium retention is seen until around 30 days, after which the production/retention stabilised. The retained magnesium concentration stabilised at $0.190-0.195 \mathrm{~mol} / \mathrm{l}$ for all four samples irrespective of the wettability and initial saturations. The produced calcium concentration stabilised at $0.020-0.025 \mathrm{~mol} / \mathrm{l}$ and 0.025-0.030 mol/l for water wet and mixed wet cores, respectively. Further, in Fig. 7b-d, when $\mathrm{MgCl}_{2}$ flooding rate was increased fourfold to $0.040 \mathrm{ml} / \mathrm{min}$, the produced calcium concentration decreased to around $0.020-0.022 \mathrm{~mol} / \mathrm{l}$, whereas it remained almost unchanged (0.020-0.024 mol/l) for the water wet sample M1 (Fig. 7a). The change in magnesium concentration was found to be less sensitive to flow rate than for calcium, and the flow rate sensitivity for magnesium ions was the same for water wet and mixed wet samples. When the flow rate decreased to $0.010 \mathrm{ml} / \mathrm{min}$, the magnesium concentration also decreased to around $0.180-0.185 \mathrm{~mol} / \mathrm{l}$ for all four cores, and the calcium concentration increased to around $0.025-0.030 \mathrm{~mol} / 1$ and $0.033-0.038 \mathrm{~mol} / \mathrm{l}$ for water wet and mixed wet cores, respectively. Similar trends were seen for $\mathrm{MgCl}_{2}$ flow through Kansas chalk (Sachdeva et al. 2019). 
(a)

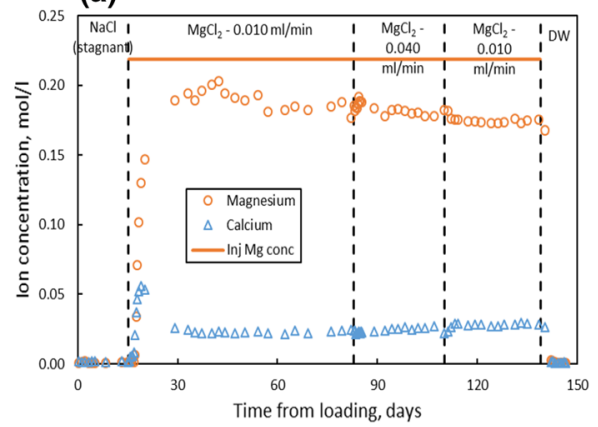

(c)

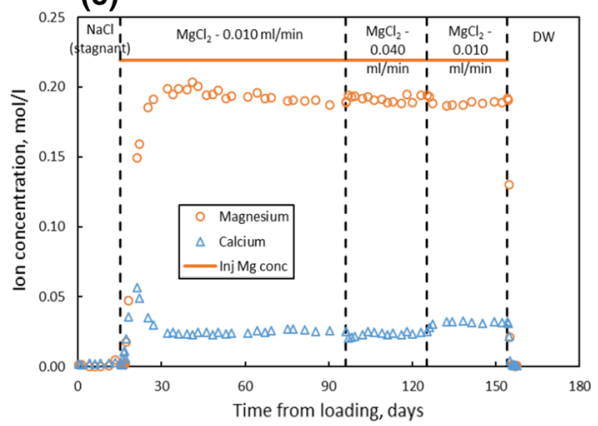

(b)

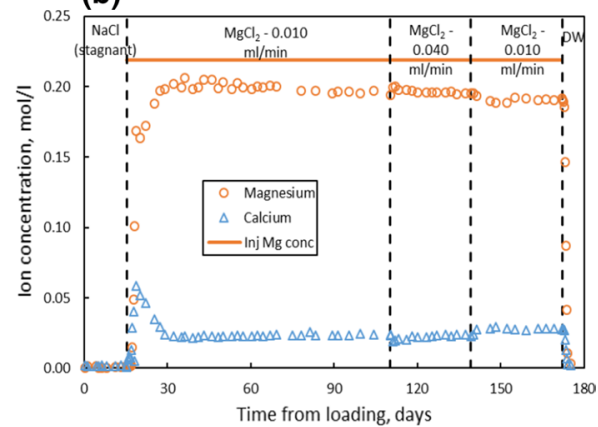

(d)

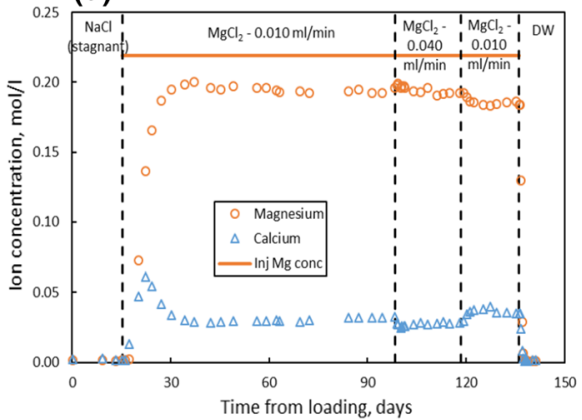

Fig. 7 Samples flooded by $0.219 \mathrm{M} \mathrm{MgCl}_{2}$ brine. Effluent ion concentrations of calcium and magnesium and the injected magnesium concentration are shown for water wet cores a M1 and b M2, and mixed wet cores $\mathbf{c}$ M3 and d M4

During cleaning with DW, the calcium and magnesium concentrations fell to zero for all cores, confirming that negligible interactions occurred.

The production rate of calcium and retention rate of magnesium, in units of gram per day, were obtained from a product of the ion concentration change, molar weight and flow rate (Fig. 8). The analysis was done from the core perspective; hence, magnesium retained is positive and calcium produced is negative. For all cores, the rate of change of these two ions was zero during bypassing of $\mathrm{NaCl}$ brine for the first 15 days as the flow rate through the cores was zero. When $\mathrm{MgCl}_{2}$ injection started through the cores at a rate of $0.010 \mathrm{ml} /$ min, a peak in the retention and production rates of magnesium and calcium is seen. The magnesium retention rate stabilised around $0.010 \mathrm{~g} / \mathrm{day}$, whereas the calcium production rate stabilised around 0.013-0.016 g/day after 15 days of flooding (molecular weights of $\mathrm{Ca}^{2+}$ and $\mathrm{Mg}^{2+}$ are $40 \mathrm{~g} / \mathrm{mol}$ and $24 \mathrm{~g} / \mathrm{mol}$, respectively). In all the effluent samples indicated that the dry mass reduced during $\mathrm{MgCl}_{2}$ flow.

When the flow rate increased four times to $0.040 \mathrm{ml} / \mathrm{min}$, the retention rate of magnesium increased to $0.029-0.057 \mathrm{~g} / \mathrm{day}$ and the calcium dissolution rate to $0.047-0.060 \mathrm{~g} /$ day. Hence, an increase of 3 to 6 times in the magnesium retention rate and that of 3 to 4 times in calcium production rate were observed. When the flow rate reduced to $0.010 \mathrm{ml} /$ min, the magnesium retention and calcium production rates dropped to $0.013 \mathrm{~g} / \mathrm{day}$ and $0.017-0.023 \mathrm{~g} /$ day, respectively. When DW was injected, the magnesium retention and calcium production rates fell to zero. The sensitivity to flow rate in the gain of magnesium and 
(a)

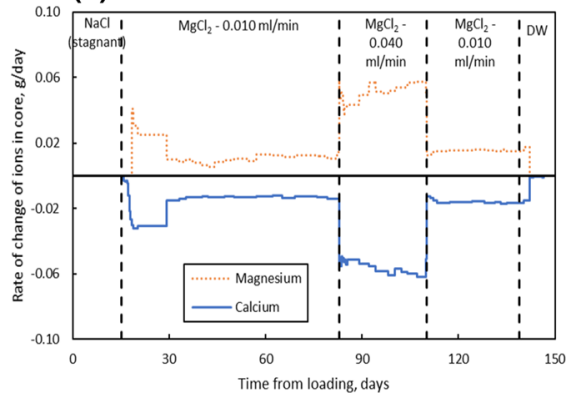

(c)

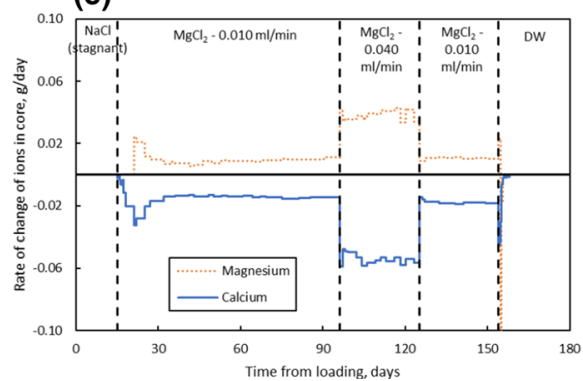

(b)

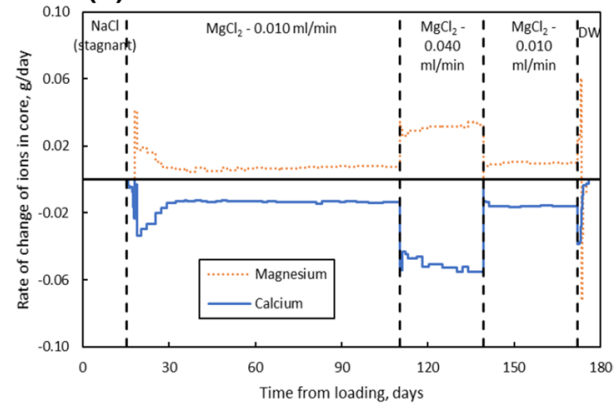

(d)

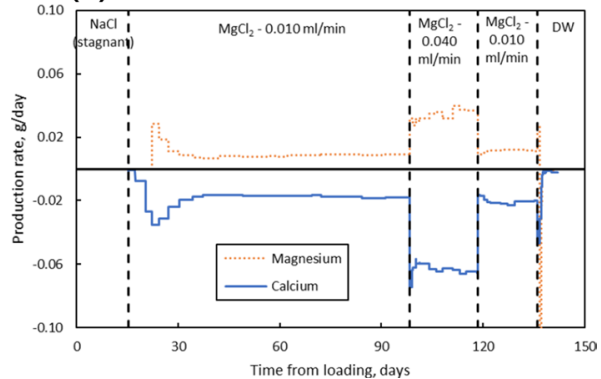

Fig. 8 Samples flooded by $0.219 \mathrm{M} \mathrm{MgCl}_{2}$ brine. Rate of change of calcium and magnesium ions in the core (g/day) is plotted as a function of time for $100 \%$ brine-saturated water wet cores a M1 and b M2, and oil/brine-saturated mixed wet cores c M3 and d M4

loss of calcium (from core perspective) was independent of the wettability and presence of oil implying that sufficient water wet areas existed for the fluid to equilibrate within the core.

\subsection{Oil Production from the Mixed Wet Core (M4) During $\mathrm{MgCl}_{2}$ Flow}

Oil production as a function of time for the core M3 was omitted due to uncertainty in the oil volume readings because of emulsification of the produced fluids. Hence, only measurements for the M4 test are presented here (Table 5). The oil produced, due to $\mathrm{MgCl}_{2}$ flow and compaction, was measured in a gravity separator on the downstream side of the experiment. Readings were recorded from digital photographs taken once every $6 \mathrm{~h}$ during the first 30 days, followed by once every $24 \mathrm{~h}$ for the rest of the test period using a digital camera.

The irreducible water saturations of M3 and M4 were estimated to be $33.7 \%$ and $36.4 \%$ with initial oil in place of $22.5 \mathrm{ml}$ and $21.0 \mathrm{ml}$ before test started. For the M4 test, $0.3 \mathrm{ml}$ of oil was produced due to expansion of oil during temperature increase from ambient to $130{ }^{\circ} \mathrm{C}$. Figure $9 \mathrm{a}$ shows the oil with time together with the water volume estimated from Eq. (13) where the bulk volume, solid volume and pore volume used are displayed in Fig. 10, which also displays the porosity evolution with time. In Fig. 9b, the oil saturation inside the core throughout the test from the start of hydrostatic loading using Eq. (14) is plotted. Before loading, when the sample was mounted, the oil and water volumes were 
Table 5 Initial and final oil and water volumes in mixed wet cores $\mathrm{M} 3$ and $\mathrm{M} 4$ during $\mathrm{MgCl}_{2}$ brine flow

\begin{tabular}{lll}
\hline Core & $\mathrm{M} 3$ & $\mathrm{M} 4$ \\
\hline Irreducible water volume before test & $11.5 \mathrm{ml}$ & $12.0 \mathrm{ml}$ \\
Irreducible water saturation $S_{\mathrm{wi}}$ & $33.7 \%$ & $36.4 \%$ \\
Initial oil volume & $22.5 \mathrm{ml}$ & $21.0 \mathrm{ml}$ \\
Total oil produced at the end of test & N.A. & $11.2 \mathrm{ml}$ \\
Oil volume after test & N.A. & $9.8 \mathrm{ml}$ \\
Oil saturation after test $S_{\text {or }}$ & N.A. & $41.4 \%$ \\
Pore volume before and after test & $34.0 \mathrm{ml}$ and $20.4 \mathrm{ml}$ & $33.0 \mathrm{ml}$ and $23.7 \mathrm{ml}$ \\
\hline
\end{tabular}

(a)

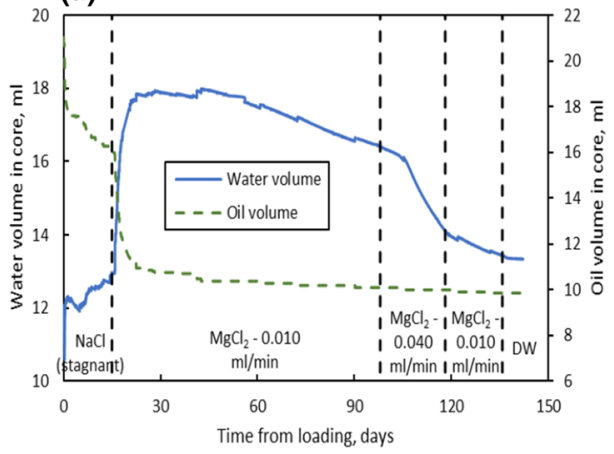

(b)

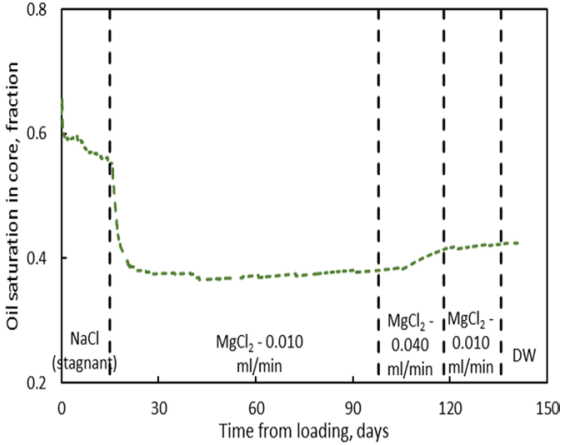

(c)

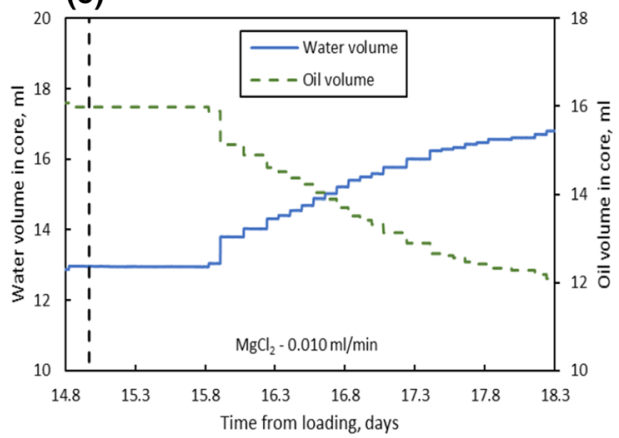

Fig. 9 Oil and water volumes with time in the mixed wet sample (M4). a Oil and water volumes from measurements of oil volume (separator), bulk volume (compaction) and solid volume (IC effluent analysis), b oil saturation in the core with time, and c zoomed into oil and water volumes in the core from 14.8 to 18.3 days. Black dashed vertical lines depict the time when brine composition and/or flow rate changed

$20.7 \mathrm{ml}$ and $12.3 \mathrm{ml} .1 .4 \mathrm{ml}$ of oil was produced during hydrostatic loading to 1.5 times yield, reducing the oil volume to $19.3 \mathrm{ml}$. During the no-flow period, $3.3 \mathrm{ml}$ of oil was produced due to compaction, which led the oil volume inside the core to further decrease to $16.0 \mathrm{ml}$ by the end of the 15 th day, in all $4.7 \mathrm{ml}$ oil was produced. During this time, the bulk volume of the sample reduced from $78.4 \mathrm{ml}$ before (Table 1) to $74.2 \mathrm{ml}$ (Fig. 10c) at 
(a)

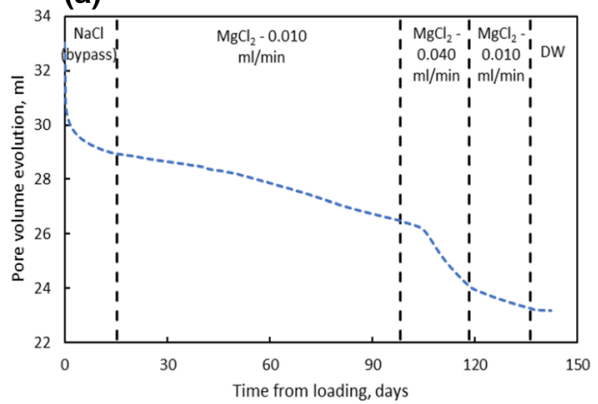

(c)

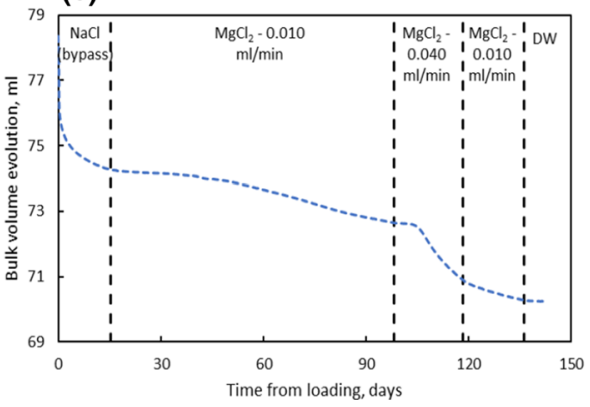

(b)

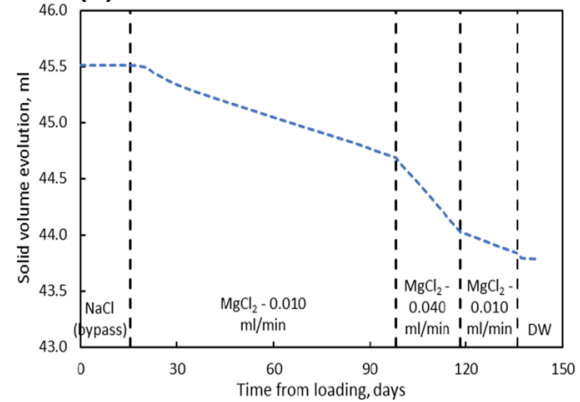

(d)

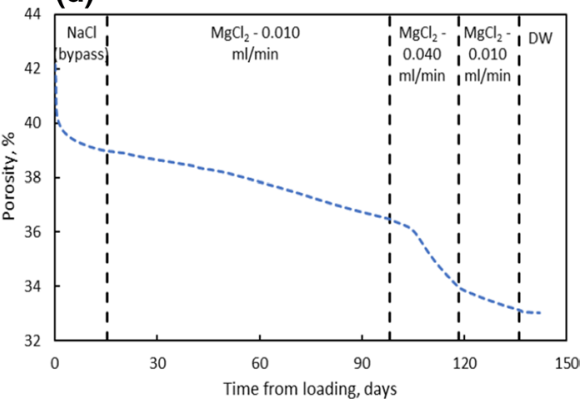

Fig. 10 a Pore volume, $\mathbf{b}$ solid volume, $\mathbf{c}$ bulk volume and $\mathbf{d}$ porosity evolution with time for mixed wet Mons core M4

15 days, i.e. a $4.2 \mathrm{ml}$ reduction. Given that the solid volume is constant, the bulk volume reduction equals the reduction in pore volume $\left(\Delta V_{b}=\Delta V_{p}\right)$. This implies that oil is primarily being produced during compaction, while the water is stagnant inside the core during mechanical loading and creep with no flow.

When $\mathrm{MgCl}_{2}$ injection started, a total of $4.8 \mathrm{ml}$ of oil was produced in the first five days (approximately 2.5 PVs flooded), followed by another $1.1 \mathrm{ml}$ in the next 78 days while flooding and compaction co-existed. After increasing the rate to $0.040 \mathrm{ml} / \mathrm{min}$, only $0.2 \mathrm{ml}$ oil produced during the next 20 days, and another $0.1 \mathrm{ml}$ oil produced after reducing it to $0.010 \mathrm{ml} / \mathrm{min}$. At the end of the $\mathrm{MgCl}_{2}$ injection phase the oil volume in the core reduced to $9.8 \mathrm{ml}$. Figure $9 \mathrm{c}$ displays a zoomed version of the oil and water volumes in the core at the start of $\mathrm{MgCl}_{2}$ injection phase after the no-flow period. The bulk volume changed during compaction (see Eq. 9), and the solid volume changed due to non-equilibrium flow (see Eq. 10).

The increase in $\mathrm{MgCl}_{2}$ flow rate to $0.04 \mathrm{ml} / \mathrm{min}$ on the 98th day did not lead to any significant additional oil production. At the same time, as presented in Fig. 8, the calcium dissolution and magnesium retention rates (in g/day) increased by a factor of 3 to 6 . This did not affect the oil recovery rate. Further on, though pore volume decreased with time because of compaction, only water was expelled from the core. Consequently, the oil saturation increased from 90 days and onwards (Fig. 9b). 
(a)

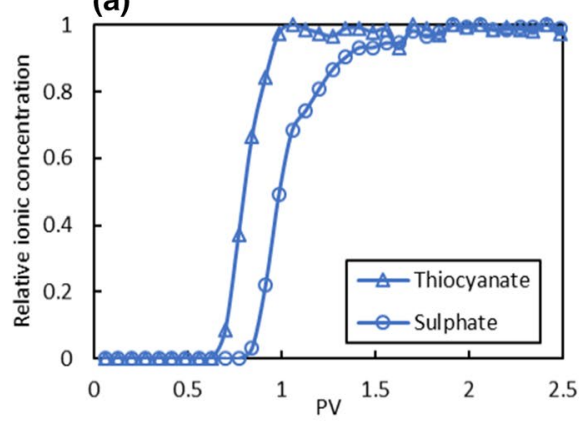

(c)

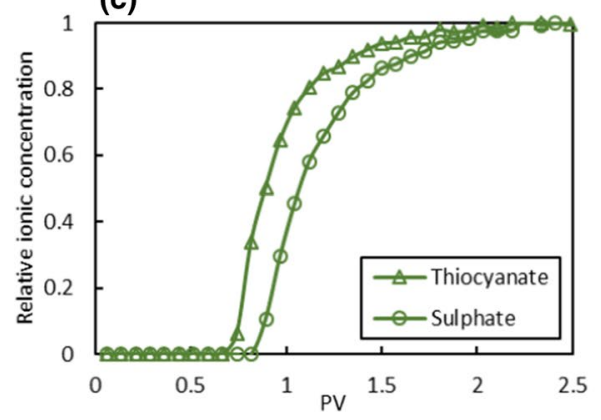

(b)

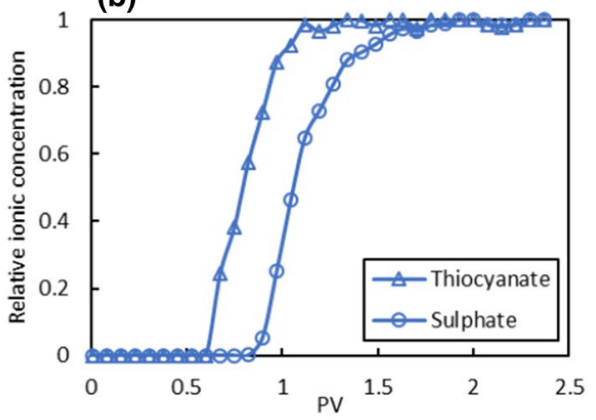

(d)

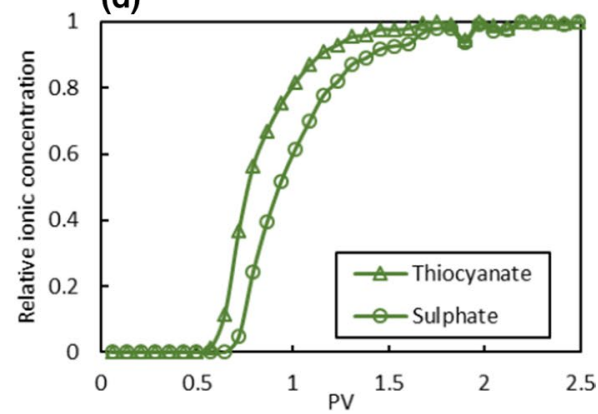

Fig. 11 Chromatographic separation tests performed on water wet cores a M1 and b M2, and mixed wet cores c M3 and d M4 at ambient temperature after mechanical tests. The plots show reduced ion concentrations of the thiocyanate and sulphate ions for SW1T brine plotted as a function of PVs injected

Table 6 Integrated areas between thiocyanate and sulphate curves estimated using chromatographic separation tests performed on all samples after mechanical tests

\begin{tabular}{lllll}
\hline Core & Initial wetting state & $\begin{array}{l}\text { Estimated area between } \\
\text { sulphate and tracer }(\mathrm{PV})\end{array}$ & $\begin{array}{l}\text { Integrated sulphate-tracer area } \\
\text { per gram core }\left(\times 10^{-3} \mathrm{PV} / \mathrm{g}\right)\end{array}$ & $\begin{array}{l}\mathrm{Total} \mathrm{MgCl}_{2} \\
\text { flooded (l) }\end{array}$ \\
\hline M1 & Water wet & 0.238 & 1.84 & 2.96 \\
M2 & & 0.294 & 2.45 & 3.51 \\
M3 & Mixed wet & 0.202 & 1.69 & 3.26 \\
M4 & & 0.170 & 1.39 & 2.61 \\
\hline
\end{tabular}

For comparison, water wet cores had an integrated area of 1.41 to $1.59 \times 10^{-3} \times 10^{-3} \mathrm{PV} / \mathrm{g}$ and the mixed wet cores had an area of 0.88 to $0.98 \times 10^{-3} \mathrm{PV} / \mathrm{g}$ in the wettability determination programme (Table 3 )

\subsection{Chromatographic Separation Test After Mechanical Test}

Chromatographic separation for wettability determination was performed on all four cores after the mechanical tests completed, but before the samples were dismantled from the triaxial cell. The thiocyanate and sulphate concentrations versus PVs of SW1T flooded are shown in Fig. 11a-d. The integrated areas between thiocyanate and sulphate curves for all samples are given in Table 6. 
All cores showed an increase in the integrated areas compared to the areas obtained in the wettability determination programme (Table 3). It is observed that the available water wet area increases with an increasing number of $\mathrm{PVs}$ of $\mathrm{MgCl}_{2}$ brine flooded through the cores. From Table 6, the amount of $\mathrm{MgCl}_{2}$ flooded through water wet sample $\mathrm{M} 2$ (3.51 l) is more than that flooded through sample M1 (2.96 1). The corresponding available water wet area after the mechanical test is also higher for the M2 sample $\left(2.45 \times 10^{-3} \mathrm{PV} / \mathrm{g}\right) \mathrm{com}$ pared to the M1 sample $\left(1.84 \times 10^{-3} \mathrm{PV} / \mathrm{g}\right)$ (Table 6). The same dependencies are also seen for the mixed wet samples, where more $\mathrm{MgCl}_{2}$ brine through sample $\mathrm{M} 3$ (3.26 1) gave a higher water wet area after the triaxial test $\left(1.69 \times 10^{-3} \mathrm{PV} / \mathrm{g}\right)$ compared to the sample M4 $\left(1.39 \times 10^{-3} \mathrm{PV} / \mathrm{g}\right)$ flooded by $2.61 \mathrm{l}$. Dissolution and precipitation processes change the amount of available mineral surfaces in contact with water and are the main factors at play in both the water wet and mixed wet samples.

\subsection{Analysis of Core After Test}

Basic measurements on all four cores after the mechanical tests are reported in Table 7. The dry mass reduced by 1.3 to $2.1 \mathrm{~g}$ for all samples, while the solid density increased by $0.02-0.04 \mathrm{~g} / \mathrm{cm}^{3}$, thereby reducing solid volume by 0.8 to $1.4 \mathrm{ml}$. The samples compacted so bulk volume reduced by 8.2 to $12.7 \mathrm{ml}$. Thus, the pore volume reduced by 9.3 to $13.6 \mathrm{ml}$.

The tested samples were cut into six sections of almost equal lengths with sections numbered from the inlet (Fig. 12). The specific surface area along the sample sections and untested end pieces is reported in Table 8.

The SSA of water wet cores M1 and M2 increased from the inlet to the middle and then decreased towards the outlet. Specific surface areas of sections 1 of M1 and M2 were $2.18 \mathrm{~m}^{2} / \mathrm{g}$ and $2.40 \mathrm{~m}^{2} / \mathrm{g}$ compared to $2.13 \mathrm{~m}^{2} / \mathrm{g}$ and $2.05 \mathrm{~m}^{2} / \mathrm{g}$ for the

Table 7 Basic properties of cores measured after tests

\begin{tabular}{lllll}
\hline Core & M1 & M2 & M3 & M4 \\
\hline Length $(\mathrm{mm})$ & 70.2 & 66.0 & 66.1 & 66.9 \\
Average diameter $(\mathrm{mm})$ & 36.2 & 36.3 & 35.6 & 35.8 \\
New dry mass $\left(\Delta M_{\mathrm{s}}\right)(\mathrm{g})$ & 128.1 & 118.3 & 117.6 & 120.3 \\
& $(-1.3)$ & $(-1.6)$ & $(-2.1)$ & $(-1.7)$ \\
Saturated mass $(\mathrm{g})$ & 152.8 & 142.7 & 138.0 & 144.0 \\
New bulk volume $\left(\Delta V_{\mathrm{b}}\right)\left(\mathrm{cm}^{3}\right)$ & 71.7 & 68.2 & 65.9 & 70.2 \\
& $(-11.2)$ & $(-10.4)$ & $(-12.7)$ & $(-8.2)$ \\
New pore volume $\left(\Delta V_{\mathrm{p}}\right)\left(\mathrm{cm}^{3}\right)$ & 24.7 & 24.4 & 20.4 & 23.7 \\
& $(-10.3)$ & $(-9.5)$ & $(-13.6)$ & $(-9.3)$ \\
New porosity $(\%)$ & 34.4 & 35.8 & 31.0 & 33.8 \\
& $(-7.8)$ & $(-7.4)$ & $(-12.3)$ & $(-8.3)$ \\
New solid density $\left(\Delta \rho_{\mathrm{s}}\right)\left(\mathrm{g} / \mathrm{cm}^{3}\right)($ pycnometry) & $2.72(0.02)$ & $2.71(0.04)$ & $2.71(0.04)$ & $2.71(0.03)$ \\
New solid volume $\left(\Delta V_{\mathrm{s}}\right)\left(\mathrm{cm}^{3}\right)($ pycnometry) & 47.1 & 43.7 & 43.4 & 44.4 \\
& $(-0.8)$ & $(-1.2)$ & $(-1.4)$ & $(-1.1)$ \\
Ratio of volumetric to axial strain $(X)$ & 3.87 & 3.12 & 3.99 & 3.84 \\
Test time (days) & 147.9 & 176.0 & 158.1 & 142.2 \\
\hline
\end{tabular}

Changes compared to the corresponding initial values are given in parenthesis 
Fig. 12 Specific surface area tested along the length of the sample

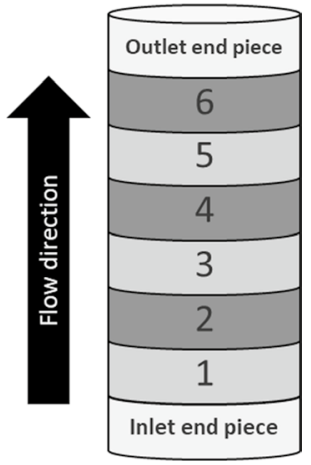

Table 8 Specific surface area measurements of unflooded core material from both sides of the core, and for sections along the length of the cores M1 to M4 after tests

\begin{tabular}{|c|c|c|c|c|}
\hline \multirow{3}{*}{$\begin{array}{l}\text { Core } \\
\text { Core section }\end{array}$} & M1 & M2 & M3 & M4 \\
\hline & \multicolumn{2}{|l|}{ Water wet } & \multicolumn{2}{|l|}{ Mixed wet } \\
\hline & $\mathrm{SSA}, \mathrm{m}^{2} / \mathrm{g}$ & $\mathrm{SSA}, \mathrm{m}^{2} / \mathrm{g}$ & $\mathrm{SSA}, \mathrm{m}^{2} / \mathrm{g}$ & $\mathrm{SSA}, \mathrm{m}^{2} / \mathrm{g}$ \\
\hline Outlet end piece (unflooded) & 1.82 & 1.98 & 2.11 & 1.96 \\
\hline 6 & 2.33 & 2.26 & 2.20 & 2.02 \\
\hline 5 & 2.47 & 2.43 & 2.14 & 2.08 \\
\hline 4 & 2.45 & 2.49 & 2.39 & 2.44 \\
\hline 3 & 2.45 & 2.46 & 2.55 & 2.45 \\
\hline 2 & 2.47 & 2.49 & 3.05 & 2.82 \\
\hline 1 & 2.18 & 2.40 & 3.35 & 3.02 \\
\hline Inlet end piece (unflooded) & 2.13 & 2.05 & 2.22 & 2.17 \\
\hline
\end{tabular}

unflooded end pieces. They increased to $2.45 \mathrm{~m}^{2} / \mathrm{g}$ and $2.49 \mathrm{~m}^{2} / \mathrm{g}$ at the middle and then decreased to $2.33 \mathrm{~m}^{2} / \mathrm{g}$ and $2.26 \mathrm{~m}^{2} / \mathrm{g}$ at the outlet for M1 and M2, respectively. Mixed wet cores M3 and M4 showed a large increase in the SSA of the inlet sections $\left(3.35 \mathrm{~m}^{2} / \mathrm{g}\right.$ and $3.02 \mathrm{~m}^{2} / \mathrm{g}$, respectively, compared to $2.22 \mathrm{~m}^{2} / \mathrm{g}$ and $2.17 \mathrm{~m}^{2} / \mathrm{g}$ for the unflooded end pieces), followed by a gradual decrease from the inlet to the outlet of the flooded samples. The SSA decreased to $2.20 \mathrm{~m}^{2} / \mathrm{g}$ and $2.02 \mathrm{~m}^{2} / \mathrm{g}$ at the outlet for M3 and M4, respectively.

\section{Discussion}

The effect of wettability on stiffness, strength and time-dependent deformation of Mons chalk is documented in this study, and then the results are compared to the Kansas chalk reported in Sachdeva et al. (2019). The key premise is perturbing the experimental conditions (ageing time, ageing temperature, oil composition, brine composition, etc.) to alter the forces at particle level that integrate to the overall core scale geomechanical properties. 


\subsection{Wettability Alteration}

In the wettability determination programme, chromatographic separation was performed on three mixed wet and three reference water wet Mons chalk samples. Based on these measurements, we assume the wettability index of the mixed wet samples in the triaxial test programme to be $0.63 \pm 0.07$ (Table 3 ). Two aged wettability-altered and two water wet samples were loaded hydrostatically and kept at 1.5 times yield stress over time, and later flooded by $\mathrm{MgCl}_{2}$ brine at varying rate.

\subsection{Impact of Wettability on Elastic Stiffness and Plastic Strength}

Beyond the experimental uncertainty, the geomechanical properties of stiffness and yield strength showed insignificant differences for water wet and mixed wet Mons samples. This is contrary to the Kansas samples reported in Sachdeva et al. (2019) where mixed wet samples were systematically stronger and stiffer than water wet samples. The initial soft behaviour at low stresses, i.e. the initial large strains of the water wet Mons samples, can be caused by closure of micro-cracks and fractures formed due to the sample handling. Further experiments are required to identify if the mechanical parameters for Mons samples can be altered by ageing, e.g. with a more acidic oil, higher ageing temperature/time, or by lowering $S_{\mathrm{wi}}$ even more before oil is injected.

\subsection{Oil Adsorption Impact Particle-Particle Contact Forces}

The thickness of the charged diffusive layer on calcite surfaces is characterised by the Debye length (Lyklema 2005; Megawati et al. 2013; Voake et al. 2019) that increases with increasing temperature (Andreassen and Fabricius 2010). A thickening of the layer (Debye length) increases the repulsive area between particles causing further weakening of water-saturated samples. Voake et al. (2019) further reported a Debye length of around $200 \mathrm{~nm}$ at $130{ }^{\circ} \mathrm{C}$ using the Debye-Hückel theory.

The force between particles in the presence of water is dictated by the sum of attractive van der Waals forces and repulsive electrostatic forces from the overlapping diffusive layer (Nermoen et al. 2018). When oil replaces water on surface areas where the double layers would otherwise interact (regions with electrostatic repulsion), the disjoining pressure would reduce and the overall force balance between particles would change. When the normal force between two grains increase (in the case of oil adsorption), it becomes harder for particles to re-organise. This seems to have occurred in Kansas (Sachdeva et al. 2019), which has a Biot coefficient of 0.91 (Voake et al. 2019) and smaller pore size (characterised by the lower relaxation time $T_{2}$ estimated from the NMR studies, Voake et al. 2019) than Mons with a Biot coefficient of 0.95 (Fig. 13a and Table 9 in "Appendix"). If oil adsorbs on mineral surfaces but not on nearby particle contacts, the geomechanical parameters would remain unaffected. This seems to have occurred in Mons (Fig. 13b).

With the same oil, brine composition and ageing temperature as here, Sachdeva et al. (2018) reported that Kansas chalk remains water wet if the ageing time is less than 6 days, and ageing for 21 days was enough to obtain a stable wettability. It remains to be tested how mechanical parameters changed for the same oil/water saturation for unaged samples. 


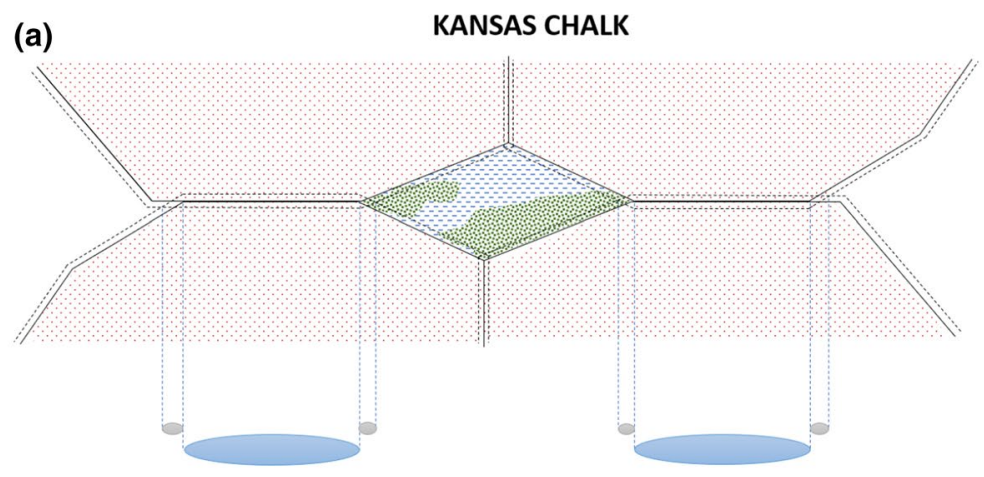

(b) MONS CHALK
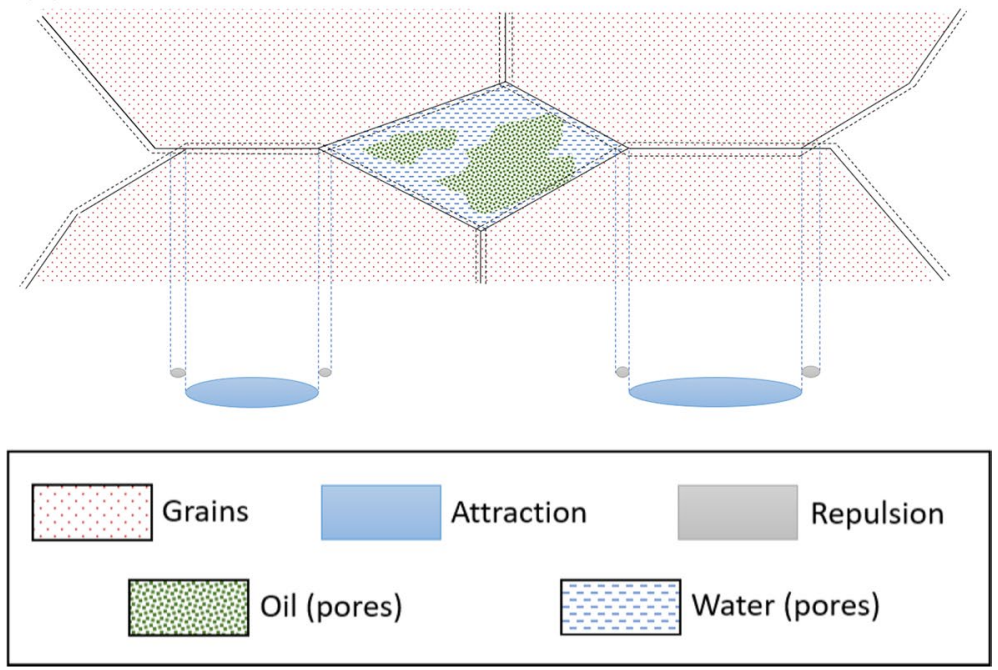

Fig. 13 Partitioning of oil and water in pores for $\mathbf{a}$ Kansas and $\mathbf{b}$ Mons chalks. Attractive van der Waals and repulsive electrostatic forces present between calcite grains are also shown. Mons chalk has larger pore size and Biot coefficient compared to Kansas chalk (Voake et al. 2019)

If ageing conditions were modified, the Mons chalk may become more mixed/oil wet, thereby affecting stiffness and strength differently than in this study.

\subsection{Impact of Wettability on Creep Behaviour During $\mathrm{MgCl}_{2}$ Injection}

The volumetric creep strain at constant creep stresses (in Table 4) followed a comparable trend for all samples throughout the creep period (Fig. 5). The injection of $\mathrm{MgCl}_{2}$ brine induced chemical reactions leading to additional creep rates (Nermoen et al. 2015). When $\mathrm{MgCl}_{2}$ brine was injected at $0.010 \mathrm{ml} / \mathrm{min}$, the strain rate curve continued to follow a decreasing trend for around 15 days, after which it stayed constant (Fig. 6). This has also been seen for other clean chalks, e.g. Mons and Stevns Klint (Andersen et al. 2018). 
All cores showed an accelerated strain when the flow rate was increased to $0.040 \mathrm{ml} / \mathrm{min}$ (Fig. 5), the strain rate increased by a factor of 3 to 8 , and the calcium production and magnesium retention increased by a factor 3 to 6 (Fig. 8). These results show how chemical reactions drive solid volume changes (reduce solid mass and increase mineral density), and how this behaviour links to bulk creep strain rate, also seen in Nermoen et al. (2016) and Andersen et al. (2018).

During DW flooding, the strain rate dropped down to zero instantly depicting that the electrostatic repulsion between neighbouring particles, when the pores are saturated by salty brines, vanishes. It is important to notice that both the chemical reaction dynamics observed by IC analysis and the sensitivity of the creep rate to the chemical reactions are independent of the oil/water saturation and the initial wetness. This is interpreted to be caused by a shift in the overall force balance between particles, occurring in all samples, where the particle-particle dynamics are controlled by the attractive van der Waals forces and a varying electrostatic repulsion. When the electrostatic repulsion is reduced, the particle-particle friction overcomes the local shear stresses, thereby halting the re-organisation.

\subsection{Calcite-NaCl Brine Interactions During Hydrostatic Loading and Creep}

When $\mathrm{NaCl}$ brine was injected into Liège chalk, dissolution of calcite was observed (Madland et al. 2011). In our case, the samples were only saturated by $\mathrm{NaCl}$, and not flooded, and as shown in Fig. 7 the concentration of calcium produced was in the range $0.001-0.003 \mathrm{~mol} / \mathrm{l}$. This means that around $0.0001 \mathrm{~mol}(0.01 \mathrm{~g})$ of calcite dissolved from a $100 \% \mathrm{NaCl}$ brine-saturated core (with a PV of approximately $34 \mathrm{ml}$ ), which amounted to approximately $0.01 \%$ in mass compared to the initial dry mass of the samples (approximately $125 \mathrm{~g}$ ). This percentage would be even less for the mixed wet samples due to the initial irreducible water saturation ranging from 31 to $38 \%$. Therefore, the $\mathrm{NaCl}$ brine-rock interactions can be neglected.

\subsection{Adsorption/Desorption Dynamics on the Calcite Surfaces}

The calcite mineral surface possesses positively charged $\mathrm{Ca}^{2+}$ and negatively charged $\mathrm{CO}_{3}{ }^{2-}$ surface sites (Stipp 1999) that lead to the adsorption of positive and negative ions from the pore fluid. When the pore fluid composition is changed, a new surface-equilibrium between the mineral surface and the ion concentration of the pore is established. The desorption and adsorption dynamics occur typically within the first PVs injected, dependent upon the ion concentration of the injected brine. When $\mathrm{MgCl}_{2}$ brine was injected through all cores, a plateau in the concentration of the produced effluent was established after approximately 15 days (from 16th day till around 30th day, i.e. approximately 6.5 PVs injected, Fig. 7), after which the magnesium and calcium concentrations are dominated by dissolution and precipitation processes.

\subsection{Interactions of Calcite with DW During Sample Cleaning}

The solubility of calcite in DW at $25{ }^{\circ} \mathrm{C}$ is $0.013 \mathrm{~g} / \mathrm{l}$ which decreases with increase in temperature (Coto et al. 2012). If the PV is $34 \mathrm{ml}, 0.00044 \mathrm{~g}$ of calcite could dissolve per PV during DW flow at $25^{\circ} \mathrm{C}$. In this study, four PVs of DW were flooded for cleaning at 
$130{ }^{\circ} \mathrm{C}$. Therefore, the dissolved calcite would be less than $0.0018 \mathrm{~g}$, i.e. less than $0.0015 \%$ of the initial dry mass (approximately $125 \mathrm{~g}$ ). Hence, any calcite dissolved during DW flooding can be neglected, as is also shown in the effluent analysis (Figs. 7, 8).

\subsection{Chemical Alterations Along the Axis of the Core}

The non-homogeneous chemical replacement dynamics are observed in the specific surface area measurements (Table 8). The SSA of water wet cores increases towards the middle of the core and then decreases towards the outlet, whereas the SSA of the mixed wet cores decreases towards the outlet with the highest value observed at the inlet of the samples. Andersen et al. (2018) demonstrated that the SSA of the water wet Mons chalk decreased from the inlet to the outlet. The non-homogenous chemical replacement dynamics were also observed in the SSA measurements of Kansas cores as reported in Sachdeva et al. (2019), where the change in SSA was non-uniform through the core. The trends obtained in Kansas cores were not clear, except that the SSA increased from the inlet towards the middle of the samples, indicative of how the dissolution/precipitation rates combine with the flow rate to develop a spatial pattern.

\subsection{Dynamic Bulk, Solid and Pore Volume Measurements}

Figure 10 shows how $\mathrm{MgCl}_{2}$ flow rate affects the different volumes with time. Solid volume decreases due to dissolution of calcite and precipitation of secondary 'smaller' magnesium-bearing minerals. Pore volume decreases due to compaction by grain reorganisation; however, pore volume is not reduced that much as an effect of the non-equilibrium flow due to the fact that solid volume is also reduced. The rate at which solid volume changes is larger when the injection rate of $\mathrm{MgCl}_{2}$ is higher $(0.040 \mathrm{ml} / \mathrm{min})$. There is also a time lag of around 5 days (similar to shown in Andersen et al. 2018) in the bulk volume evolution when the flow rate of $\mathrm{MgCl}_{2}$ is increased from 0.010 to $0.040 \mathrm{ml} / \mathrm{min}$. This transient period in Fig. 10 (also observed in Fig. 5 at the start of $\mathrm{MgCl}_{2}$ flooding at a higher rate of $0.040 \mathrm{ml} / \mathrm{min}$ ) shows the delayed weakening during reactive flow of $\mathrm{MgCl}_{2}$, i.e. a delay in the accelerated strain by increased pore collapse rate at constant stress and temperature conditions. We interpret that the rock framework (acting as force chains) can withstand the chemical reactions for some time. These force chains are dependent upon stresses focussing the dissolution to the load bearing parts (which in our case is the solid framework or the grain-grain contacts following the force chains) of the material, and thus a delayed failure occurs. After this transient period, the bulk volume decreases at an accelerated rate. During the flooding of DW before demounting, no change in the pore volume, solid volume and bulk volume is observed.

\subsection{Comparing the Observed Mechanical Response with Kansas Chalk}

Both Kansas and Mons chalks are from Cretaceous age. Mons chalk has $>99$ wt $\%$ calcite content, whereas Kansas chalk has around 95-97 wt\% calcite content. Kansas chalk has gone through a higher degree of diagenesis (Finn and Johnson 2005) than the Mons chalk 
(Pirson et al. 2008). Previous XRD analyses of the clay fraction $(<2 \mu \mathrm{m})$ from these two chalk types have shown differences in their mineralogical assemblage, indicative of different diagenetic conditions (Bertolino et al. 2013; Andersen et al. 2018).

The mechanical parameters of Mons chalk obtained in this study are compared to those obtained from Kansas chalk reported by Sachdeva et al. (2019). These chalks differ in their wettability values even though the ageing procedure was the same. The wettability for the mixed wet Kansas chalk was reported to be $0.55 \pm 0.05$, whereas mixed wet Mons chalk gave the wetting indices of $0.63 \pm 0.07$ (Table 3). During loading with stagnant and inert fluids inside the pores, the behaviour observed for Mons differs from Kansas chalk, where a clear difference in both stiffness and strength in response to wettability alteration between the mixed wet samples and water wet samples was seen (Sachdeva et al. 2019).

During time-dependent creep, water wet and mixed wet Kansas chalks gave a similar creep trend irrespective of the presence of oil (Sachdeva et al. 2019). Similarly, comparable trends were observed for Mons chalk. Strain rates reduced for all Mons cores at the start of $\mathrm{MgCl}_{2}$ flood (Fig. 6). It was followed by an increase in strain rates for all cores after approximately 15 days of $\mathrm{MgCl}_{2}$ injection. In all tests, strain rates increased even more as flow rate was increased fourfold, followed by a reduction when flow rate was reduced again. The strain rates dropped to zero for all cores during DW injection. The creep slopes were not the same for all cores; however, their response to changes in brine composition and flow rates was the same. Similar observations were documented for Kansas chalk cores (Sachdeva et al. 2019).

\subsection{Oil Production During Compaction and Flow}

During hydrostatic loading and no-flow creep period (up to 15th day), $4.7 \mathrm{ml}$ oil was produced from mixed wet Mons M4 core. Hence, deformation contributed to $43 \%$ of the total oil recovered after the initial thermal expansion. This value is comparable to the bulk volume loss of the sample (i.e. $\Delta V_{\mathrm{s}}=\Delta V_{\mathrm{p}}=\Delta V_{\text {oil }}$ ). Given that the water was not mobilised, it implies that oil was the mobile phase during compaction. After the first 15 days of creep, $\mathrm{MgCl}_{2}$ was injected. In this phase, all the oil was produced during the initial 2-3 PVs, and thereafter despite the ongoing chemical reactions and compaction negligible oil volume was produced from the core. This shows that the non-equilibrium rock-fluid interactions between the calcite surface and $\mathrm{MgCl}_{2}$ brine did not contribute to any tail-end recovery after the initial viscous displacement. The observed oil production was compared to the chromatographic separation tests after mechanical tests. It was deduced that the observed increase in the integrated area of the mixed wet samples is related to the creation of new mineral phases due to precipitation rather than the mobilisation of oil volumes wetting the mineral phases.

On the other hand, no oil was produced during the loading and the creep phase due to compaction for Kansas chalk. Further, no oil was recovered during $\mathrm{MgCl}_{2}$ injection through mixed wet Kansas chalk after the initial displacement (Sachdeva et al. 2019). The recovery of oil from Mons chalk due to compaction is likely due to the fact that it is more water wet $\left(W_{\mathrm{i}}\right.$ of $0.63 \pm 0.07$, Table 3$)$ to start with compared to the mixed wet Kansas chalk ( $W_{\mathrm{i}}$ of $0.55 \pm 0.05$ ). Mixed wet Mons M4 core also has a larger volumetric strain during loading and creep in the stagnant phase compared to the Kansas mixed wet cores, 
which may also have resulted in oil production from Mons chalk. Kansas chalk also has a smaller pore size than Mons (Voake et al. 2019), and due to the capillary forces, they need the extra flow energy from the injection brine to produce oil. However, it remains to be tested how compaction-driven multiphase flow and geomechanical properties are changed for unaged oil/water-saturated Kansas and Mons chalk samples.

\subsection{Summary of the Discussion}

The water wet and mixed wet Mons samples showed insignificant differences in stiffness and yield strength measurements, whereas the mixed wet Kansas samples were stiffer and stronger than their water wet counterparts. During creep with a stagnant phase and a following $\mathrm{MgCl}_{2}$ brine injection phase, both Mons and Kansas chalks showed similar response to changes in brine compositions and flow rates irrespective of the initial wettability and oil/water saturations. Even though $\mathrm{MgCl}_{2}$ brine led to time-dependent weakening, i.e. increased strain rates, it did not lead to any additional oil recovery at the tested flow rates. This may be due to: (a) even though a change in the wetting state is observed for mixed wet Mons cores M3 and M4, $\mathrm{MgCl}_{2}$ brine was not able to mobilise the oil stuck on the walls, meaning the new surfaces formed due to precipitation of magnesium-bearing minerals were all in contact with the water phase, and/or (b) pressure difference across the oil ganglia is insufficient to overcome capillary forces (also discussed in Sachdeva et al. 2019). Hence, the combined observations from Kansas chalk (in Sachdeva et al. 2019) showed that neither compaction nor non-equilibrium flow contribute to oil production after the initial displacement. On the other hand, Mons chalk showed that compaction contributes to oil production up to a certain extent, but non-equilibrium flow does not. It will be important to study, in the future, the effect of increasing the flow rate even more to study the potentiality of $\mathrm{MgCl}_{2}$ brine to improve oil recovery at higher rates.

\section{Conclusions}

We have investigated how $\mathrm{MgCl}_{2}$ brine injection through hydrostatically stressed Mons chalk impacts (a) stiffness and strength, (b) time-dependent deformation at constant stresses and (c) oil production. All samples were loaded to a stress level of 1.5 times the compaction yield strength. The experiments were performed on both water wet and mixed wet samples. We compared the observed mechanical response to a similar test series conducted on a different chalk type (Kansas) to display how petrophysical differences impact the overall dynamics.

The water wet and wettability-altered Mons samples had a similar strength and stiffness, while the wettability-altered Kansas samples were stiffer and stronger than their water wet counterparts.

The volumetric creep strain and strain rates for the different wettability cores followed a comparable trend during the stagnant fluid period. The creep response to the injection of $\mathrm{MgCl}_{2}$ brine was also the same, irrespective of the wettability and oil/water saturation. These observations were found for both Kansas and Mons chalks. The results seem 
to indicate that the presence of oil in pores does not prevent brines to access intergranular contacts, i.e. the water weakening by $\mathrm{MgCl}_{2}$ injection prevails.

Further, IC analysis displayed that the chemical reactions were insensitive to oil in the samples implying that the injected brine can interact with the mineral surfaces. The chemical replacement observed by ion chromatography was insensitive to the presence of oil in the pores, so the outcome from experiments performed on water wet samples can be applied to actual oil reservoir scenarios.

The oil production with time measurements due to compaction in Mons chalk showed a $43 \%$ additional oil recovery before the start of reactive brine flooding, whereas no additional oil recovery was seen during this stage in Kansas chalk. After the initial oil was produced during the first 2-3 $\mathrm{PVs}$ of $\mathrm{MgCl}_{2}$ injection, neither compaction nor chemical interactions through both the Kansas and Mons chalks led to additional oil recovery.

Acknowledgements Open Access funding provided by University Of Stavanger. The authors acknowledge the Research Council of Norway and the industry partners, ConocoPhillips Skandinavia AS, Aker BP ASA, Eni Norge AS, Equinor ASA, Neptune Energy Norge AS, Lundin Norway AS, Halliburton AS, Schlumberger Norge AS, Wintershall Norge AS, and DEA Norge AS, of The National IOR Centre of Norway for support.

Funding Funding was provided by Norges Forskningsråd (Grant No. 230303).

Data Availability The data that support the findings of this study are available on request from the corresponding author.

Open Access This article is licensed under a Creative Commons Attribution 4.0 International License, which permits use, sharing, adaptation, distribution and reproduction in any medium or format, as long as you give appropriate credit to the original author(s) and the source, provide a link to the Creative Commons licence, and indicate if changes were made. The images or other third party material in this article are included in the article's Creative Commons licence, unless indicated otherwise in a credit line to the material. If material is not included in the article's Creative Commons licence and your intended use is not permitted by statutory regulation or exceeds the permitted use, you will need to obtain permission directly from the copyright holder. To view a copy of this licence, visit http://creativecommons.org/licenses/by/4.0/.

\section{Appendix}

The main differences between Kansas and Mons chalk types used to discuss the results are reported in Table 9.

Table 9 Differences between Kansas and Mons chalk types

\begin{tabular}{lll}
\hline & Kansas & Mons \\
\hline Carbonate content, \% & $95-97$ & $>99$ \\
Initial wettability index (Sachdeva et al. 2019) & $0.55 \pm 0.05$ & $0.63 \pm 0.07$ \\
Biot coefficient (Voake et al. 2019) & 0.91 & 0.95 \\
Initial porosity, \% (Sachdeva et al. 2019) & $35-38$ & $42-44$ \\
Initial water saturation, \% (Sachdeva et al. 2019) & $26-29$ & $31-38$ \\
Relaxation time $T_{2}$ from NMR studies, ms (Voake et al. 2019) & $15-80$ & $35-200$ \\
\hline
\end{tabular}




\section{References}

Ahsan, R., Fabricius, I.L.: Sorption of magnesium and sulfate ions on calcite. In: 72nd EAGE Conference and Exhibition incorporating SPE EUROPEC 2010, Extended Abstracts, SP13 (2010)

Alam, M.M., Ahsan, R., Shaik, A.K., Fabricius, I.L.: Surface charge of calcite and its influence on the electrical conductivity in chalk. In: 80th Annual International Meeting, Society of Exploration Geophysicists, Expanded Abstracts, pp. 2686-2691 (2010)

Andersen, P.Ø., Wang, W., Madland, M.V., Zimmermann, U., Korsnes, R.I., Bertolino, S.R.A., Minde, M., Schulz, B., Gilbricht, S.: Comparative study of five outcrop chalks flooded at reservoir conditions: chemo-mechanical behaviour and profiles of compositional alteration. Transp. Porous Media 121(1), 135-181 (2018)

Andreassen, K.A., Fabricius, I.L.: Biot critical frequency applied to description of failure and yield of highly porous chalk with different pore fluids. Geophysics 75(6), E205-E213 (2010)

Bertolino, S.A.R., Zimmermann, U., Madland, M.V., Hildebrand-Habel, T., Hiorth, A., Korsnes, R.I.: Mineralogy, geochemistry and isotope geochemistry to reveal fluid flow process in flooded chalk under long term test conditions for EOR purposes. In: XV International Clay Conference, Brasil, vol. 676 (2013)

Brunauer, S., Emmett, P.H., Teller, E.: Adsorption of gases in multimolecular layers. J. Am. Chem. Soc. 60(2), 309-319 (1938)

Coto, B., Martos, C., Peña, J.L., Rodríguez, R., Pastor, G.: Effects in the solubility of $\mathrm{CaCO}_{3}$ : experimental study and model description. Fluid Phase Equilib. 324, 1-7 (2012)

Fan, T., Buckley, J.S.: Acid number measurements revisited. SPE J. 12(04), 496-500 (2007)

Finn, T.M., Johnson, R.C.: Niobrara total petroleum system in the southwestern Wyoming Province. In: Chapter 6 of Petroleum Systems and Geologic Assessment of Oil and Gas in the Southwestern Wyoming Province, Wyoming, Colorado, and Utah, U.S. Geological Survey Digital Data Series DDS-69-D, U.S. Geological Survey, Denver, Colorado (2005)

Gauer, P.R., Sylte, J.E., Nagel, N.B.: Ekofisk field well log decompaction. In: Paper SPE/ISRM 78177 Presented at the Rock Mechanics Conference, Irving, Texas, October 20-23 (2002)

Heggheim, T., Madland, M.V., Risnes, R., Austad, T.: A chemical induced enhanced weakening of chalk by seawater. J. Petrol. Sci. Eng. 46, 171-184 (2005)

Hellmann, R., Renders, P.J.N., Gratier, J.P., Guiguet, R.: Experimental pressure solution compaction of chalk in aqueous solutions. Part 1. Deformation behavior and chemistry. Water Rock Interact. Ore Depos. Environ. Geochem. Trib. David A. Crerar 7(7), 129-152 (2002a)

Hellmann, R., Gaviglio, P., Renders, P.J.N., Gratier, J.P., Bekri, S., Adler, P.: Experimental pressure solution compaction of chalk in aqueous solutions. Part 2. Deformation examined by SEM, porosimetry, synthetic permeability, and X-ray computerized tomography. Water Rock Interact. Ore Depos. Environ. Geochem. Trib. David A. Crerar 7(7), 153-178 (2002b)

Henriksen, A.D., Fabricius, I.L., Borre, M.K., Korsbech, U., Theilgaard, A.T., Zandbergen, J.B.: Core density scanning, degree of induration and dynamic elastic moduli of Palaeogene limestone in the Copenhagen area. Q. J. Eng. Geol.Hydrogeol. 32(2), 107-117 (1999)

Hermansen, H., Landa, G.H., Sylte, J.E., Thomas, L.K.: Experiences after 10 years of waterflooding the Ekofisk field, Norway. J. Petrol. Sci. Eng. 26, 11-18 (2000)

Hiorth, A., Cathles, L.M., Madland, M.V.: The impact of pore water chemistry on carbonate surface charge and oil wettability. Transp. Porous Media 85(1), 1-21 (2010)

Hofmann, S., Voïtchovsky, K., Spijker, P., Schmidt, M., Stumpf, T.: Visualising the molecular alteration of the calcite (104)—water interface by sodium nitrate. Sci. Rep. 6, 21576 (2016)

Korsnes, R.I., Madland, M.V., Austad, T.: Impact of brine composition on the mechanical strength of chalk at high temperature. In: Eurock 2006: Multiphysics Coupling and Long Term Behaviour in Rock Mechanics, pp. 133-140. Taylor and Francis, London (2006a)

Korsnes, R.I., Strand, S., Hoff, O., Pedersen, T., Madland, M.V., Austad, T.: Does the chemical interaction between seawater and chalk affect the mechanical properties of chalk? In: Eurock 2006: Multiphysics Coupling and Long Term Behaviour in Rock Mechanics, pp. 427-434. Taylor and Francis, London (2006b)

Korsnes, R.I., Madland, M.V., Austad, T., Haver, S., Røsland, G.: The effects of temperature on the water weakening of chalk by seawater. J. Petrol. Sci. Eng. 60, 183-193 (2008)

Liu, J., Wani, O.B., Alhassan, S.M., Pantelides, S.T.: Wettability alteration and enhanced oil recovery induced by proximal adsorption of $\mathrm{Na}^{+}, \mathrm{Cl}^{-}, \mathrm{Ca}^{2+}, \mathrm{Mg}^{2+}$, and $\mathrm{SO}_{4}{ }^{2-}$ Ions on calcite. Phys. Rev. Appl. 10(3), 034064 (2018)

Lyklema, J.: Fundamentals of Interface and Colloid Science: Soft Colloids, vol. 5. Elsevier, Academic Press, San Diego (2005) 
Madland, M.V., Hiorth, A., Korsnes, R.I., Evje, S., Cathles, L.: Rock fluid interactions in chalk exposed to injection of seawater, $\mathrm{MgCl}_{2}$, and $\mathrm{NaCl}$ brines with equal ionic strength. In: Paper A22 Presented at the 15th European Symposium on Improved Oil Recovery, Paris, France, April 27-29 (2009)

Madland, M.V., Hiorth, A., Omdal, E., Megawati, M., Hildebrand-Habel, T., Korsnes, R.I., Evje, S., Cathles, L.M.: Chemical alterations induced by rock-fluid interactions when injecting brines in high porosity chalks. Transp. Porous Media 87, 679-702 (2011)

Madland, M.V., Midtgarden, K., Manafov, R., Korsnes, R.I., Kristiansen, T.G., Hiorth, A.: The effect of temperature and brine composition on the mechanical strength of Kansas chalk. In: Paper SCA2008-55 Presented at the International Symposium of the Society of Core Analysts, Abu Dhabi, UAE, October 29-November 2 (2008)

Maury, V., Piau, J.M., Halle, G.: Subsidence induced by water injection in water sensitive reservoir rocks: the example of Ekofisk. In: Paper SPE 36890 Presented at the SPE European Petroleum Conference, Milan, Italy, October 22-24 (1996)

Megawati, M., Andersen, P.Ø., Korsnes, R.I., Evje, S., Hiorth, A., Madland, M.V.: The effect of aqueous chemistry $\mathrm{pH}$ on the time-dependent deformation behavior of chalk experimental and modelling study. In: Pore2Fluid International Conference. 16-18 Nov, Paris, France (2011)

Megawati, M., Hiorth, A., Madland, M.V.: The impact of surface charge on the mechanical behavior of high-porosity chalk. Rock Mech. Rock Eng. 46(5), 1073-1090 (2013)

Megawati, M., Madland, M.V., Hiorth, A.: Mechanical and physical behavior of high-porosity chalks exposed to chemical perturbation. J. Petrol. Sci. Eng. 133, 313-327 (2015). https://doi. org/10.1016/j.petrol.2015.06.026

Minde, M.W., Haser, S., Korsnes, R.I., Zimmermann, U., Madland, M.V.: Comparative studies of mineralogical alterations of three ultra-long-term tests of onshore chalk at reservoir conditions. In: 19th European Symposium on Improved Oil Recovery/IOR Norway 2017. European Association of Geoscientists and Engineers. ISBN 978-94-6282-209-2 (2017)

Minde, M.W., Zimmermann, U., Madland, M.V., Korsnes, R.I., Schulz, B., Gilbricht, S.: Mineral replacement in long-term flooded porous carbonate rocks. Submitted to Geochimica et Cosmochimica Acta, publication under review (2018a)

Minde, M.W., Wang, W., Madland, M.V., Zimmermann, U., Korsnes, R.I., Bertolino, S.R., Andersen, P.Ø.: Temperature effects on rock engineering properties and rock-fluid chemistry in opal-CT-bearing chalk. J. Petrol. Sci. Eng. 169, 454-470 (2018)

Nagel, N.B.: Ekofisk field overburden modelling. In: Paper SPE 47345 Presented at the SPE/ISRM Rock Mechanics in Petroleum Engineering, Trondheim, Norway, July 8-10 (1998)

Nagel, N.B.: Compaction and subsidence issues within the petroleum industry: From Wilmington to Ekofisk and beyond. Phys. Chem. Earth Part A. 26(1-2), 3-14 (2001)

Nermoen, A., Korsnes, R.I., Hiorth, A., Madland, M.V.: Porosity and permeability development in compacting chalks during flooding of non-equilibrium brines: insights from long-term experiment. J. Geophys. Res. Solid Earth (2015). https://doi.org/10.1002/2014JB011631

Nermoen, A., Korsnes, R.I., Aursjø, O., Madland, M.V., Kjørslevik, T.A., Østensen, G.: How stress and temperature conditions affect rock-fluid chemistry and mechanical deformation. Front. Phys. 4, 2 (2016)

Nermoen, A., Korsnes, R.I., Storm, E.V., Stødle, T., Madland, M.V., Fabricius, I.L.: Incorporating electrostatic effects into the effective stress relation-insights from chalk experiments. Geophysics $\mathbf{8 3}(3)$, MR123-MR135 (2018)

Neveux, L., Grgic, D., Carpentier, C., Pirnon, J., Truche, L., Girard, J.P.: Influence of hydrocarbon injection on the compaction by pressure solution of a carbonate rock: an experimental study under triaxial stresses. Mar. Petrol. Geol. 55, 282-294 (2014a)

Neveux, L., Grgic, D., Carpentier, C., Pironon, J., Truche, L., Girard, J.P.: Experimental simulation of chemomechanical processes during deep burial diagenesis of carbonate rocks. J. Geophys. Res. Solid Earth 119(2), 984-1007 (2014b). https://doi.org/10.1002/2013JB010516

Pirson, S., Spagna, P., Baele, J.M., Damblon, F., Gerrienne, P., Vanbrabant, Y., Yans, J.: An overview of the geology of belgium. Mem. Geol. Surv. Belg. 55(5), 26 (2008)

Ricci, M., Spijker, P., Stellacci, F., Molinari, J.F., Voïtchovsky, K.: Direct visualization of single ions in the Stern layer of calcite. Langmuir 29(7), 2207-2216 (2013)

Risnes, R.: Deformation and yield in high porosity outcrop chalk. Phys. Chem. Earth (A) 26, 53-57 (2001)

Risnes, R., Haghighi, H., Korsnes, R.I., Natvik, O.: Chalk-fluid interactions with glycol and brines. Tectonophysics 370, 213-226 (2003)

Sachdeva, J.S., Nermoen, A., Korsnes, R.I., Madland, M.V.: Impact of initial wettability and injection brine chemistry on mechanical behaviour of kansas chalk. Transp. Porous Media 128, 755-795 (2019). https ://doi.org/10.1007/s11242-019-01269-z 
Sachdeva, J.S., Sripal, E.A., Nermoen, A., Korsnes, R.I., Madland, M.V., James, L.A.: A laboratory scale approach to wettability restoration in chalk core samples. In: SCA2018-020 Paper Presented at the International Symposium of the Society of Core Analysts, Trondheim, Norway, August 27-30 (2018)

Standnes, D.C., Austad, T.: Wettability alteration in chalk: 1. Preparation of core material and oil properties. J. Petrol. Sci. Eng. 28(3), 111-121 (2000a)

Standnes, D.C., Austad, T.: Wettability alteration in chalk: 2. Mechanism for wettability alteration from oilwet to water-wet using surfactants. J. Petrol. Sci. Eng. 28(3), 123-143 (2000b)

Stipp, S.L.S.: Toward a conceptual model of the calcite surface: hydration, hydrolysis and surface potential. Geochim. Cosmochim. Acta 63(19/20), 3121-3131 (1999)

Strand, S., Standnes, D.C., Austad, T.: New wettability test for chalk based on chromatographic separation of $\mathrm{SCN}^{-}$and $\mathrm{SO}_{4}{ }^{2-}$. J. Petrol. Sci. Eng. 52, 187-197 (2006a)

Strand, S., Høgnesen, E.J., Austad, T.: Wettability alteration of carbonates-effects of potential determining ions $\left(\mathrm{Ca}^{2+}\right.$ and $\left.\mathrm{SO}_{4}{ }^{2-}\right)$ and temperature. Colloids Surf. A 275(1-3), 1-10 (2006b)

Strand, S., Hjuler, H.L., Torsvik, R., Pedersen, J.I., Madland, M.V., Austad, T.: Wettability of chalk: Impact of silica, clay content and mechanical properties. Petrol. Geosci. 13(1), 69-80 (2007)

Sulak, R.M.: Ekofisk field: the first 20 years. J. Petrol. Technol. 43(10), 1-265 (1991)

Sulak, R.M., Danielsen, J.: Reservoir aspects of Ekofisk subsidence. J. Petrol. Technol. 41(7), 709-716 (1989). (SPE 17852-PA)

Sylte, J.E., Thomas, L.K., Rhett, D.W., Bruning, D.D., Nagel, N.B.: Water Induced Compaction in the Ekofisk Field. In: Paper SPE 56426 Presented at the SPE Annual Technical Conference and Exhibition, Houston, Texas, October 3-6 (1999)

Voake, T., Nermoen, A., Ravnås, C., Korsnes, R.I., Fabricius, I.L.: Influence of temperature cycling and pore fluid on tensile strength of chalk. J. Rock Mech. Geotech. Eng. (2019). https://doi.org/10.1016/j. jrmge.2018.12.004

Zhang, P., Austad, T.: The relative effects of acid number and temperature on chalk wettability. In: Paper SPE 92999 Presented at SPE International Symposium on Oilfield Chemistry, Houstan, Texas, USA, February 2-4 (2005)

Zhang, P., Austad, T.: Wettability and oil recovery from carbonates: effects of temperature and potential determining ions. Colloids Surf. A 279(1-3), 179-187 (2006)

Zhang, P., Tweheyo, M.T., Austad, T.: Wettability alteration and improved oil recovery by spontaneous imbibition of seawater into chalk: impact of the potential determining ions $\mathrm{Ca}^{2+}, \mathrm{Mg}^{2+}$, and $\mathrm{SO}_{4}{ }^{2-}$. Colloids Surf. A 301(1-3), 199-208 (2007)

Zimmermann, U., Madland, M.V., Nermoen, A., Hildebrand-Habel, T., Bertolino, S.A.R., Hiorth, A., Korsnes, R.I., Audinot, J.N., Grysan, P.: Evaluation of the compositional changes during flooding of reactive fluids using scanning electron microscopy, nano-secondary ion mass spectrometry, x-ray diffraction and whole rock geochemistry. AAPG (Am. Assoc. Pet. Geol.) Bull. 99(5), 791-805 (2015). https://doi.org/10.1306/12221412196

Publisher's Note Springer Nature remains neutral with regard to jurisdictional claims in published maps and institutional affiliations.

\section{Affiliations}

\section{Jaspreet S. Sachdeva ${ }^{1,2}$ (D) Anders Nermoen ${ }^{1,3} \cdot$ Reidar I. Korsnes $^{1,2}$. Merete V. Madland ${ }^{1,2}$}

1 The National IOR Centre of Norway, University of Stavanger, Stavanger, Norway

2 Department of Energy Resources, University of Stavanger, Stavanger, Norway

3 Norwegian Research Centre AS, Oslo, Norway 